Article

\title{
Dehydration of Biomass-Derived Butanediols over Rare Earth Zirconate Catalysts
}

\author{
Asami Matsuda ${ }^{1}$, Yoshitaka Matsumura ${ }^{1}$, Kazuki Nakazono ${ }^{1}$, Fumiya Sato ${ }^{2}$, Ryoji Takahashi ${ }^{2}$, \\ Yasuhiro Yamada ${ }^{1}$ and Satoshi Sato ${ }^{1, *}$ \\ 1 Graduate School of Engineering, Chiba University, Yayoi, Inage 263-8522, Japan; afaa8728@chiba-u.jp (A.M.); \\ afsa2393@chiba-u.jp (Y.M.); affa7171@chiba-u.jp (K.N.); y-yamada@faculty.chiba-u.jp (Y.Y.) \\ 2 Graduate School of Science and Engineering, Ehime University, 2-5 Bunkyocho, Matsuyama, \\ Ehime 790-8577, Japan; fumiya@ehime-u.ac.jp (F.S.); rtaka@ehime-u.ac.jp (R.T.) \\ * Correspondence: satoshi@faculty.chiba-u.jp; Tel.: +81-43-290-3377
}

Received: 29 October 2020; Accepted: 27 November 2020; Published: 29 November 2020

check for updates

\begin{abstract}
The aim of this work is to develop an effective catalyst for the conversion of butanediols, which is derivable from biomass, to valuable chemicals such as unsaturated alcohols. The dehydration of 1,4-, 1,3-, and 2,3-butanediol to form unsaturated alcohols such as 3-buten-1-ol, 2-buten-1-ol, and 3-buten-2-ol was studied in a vapor-phase flow reactor over sixteen rare earth zirconate catalysts at $325^{\circ} \mathrm{C}$. Rare earth zirconates with high crystallinity and high specific surface area were prepared in a hydrothermal treatment of co-precipitated hydroxide. Zirconates with heavy rare earth metals, especially $\mathrm{Y}_{2} \mathrm{Zr}_{2} \mathrm{O}_{7}$ with an oxygen-defected fluorite structure, showed high catalytic performance of selective dehydration of 1,4-butanediol to 3-buten-1-ol and also of 1,3-butanediol to form 3-buten-2-ol and 2-buten-1-ol, while the zirconate catalysts were less active in the dehydration of 2,3-butanediol. The calcination of $\mathrm{Y}_{2} \mathrm{Zr}_{2} \mathrm{O}_{7}$ significantly affected the catalytic activity of the dehydration of 1,4-butanediol: a calcination temperature of $\mathrm{Y}_{2} \mathrm{Zr}_{2} \mathrm{O}_{7}$ at $900{ }^{\circ} \mathrm{C}$ or higher was efficient for selective formation of unsaturated alcohols. $\mathrm{Y}_{2} \mathrm{Zr}_{2} \mathrm{O}_{7}$ with high crystallinity exhibits the highest productivity of 3-buten-1-ol from 1,4-butanediol at $325^{\circ} \mathrm{C}$.
\end{abstract}

Keywords: dehydration; butanediol; unsaturated alcohols; $\mathrm{Y}_{2} \mathrm{Zr}_{2} \mathrm{O}_{7}$; cubic fluorite

\section{Introduction}

Biomass has been regarded as an alternative resource to manufacture useful chemicals in the petrochemical industry. Butanediols (BDOs) such as 2,3-butanediol (2,3-BDO), 1,4-butanediol (1,4-BDO) and 1,3-butanediol (1,3-BDO) are derivable in the direct microbial conversion of renewable materials, and they are summarized in several reviews [1-7]. The microbial production of 2,3-BDO is most widely investigated among the BDO isomers and has a long history over a century [1]. 2,3-BDO is produced from corncob and kenaf core as well as sugars such as glucose, xylose, and sucrose. The production of 1,4-BDO from biomass has developed rapidly [8-11]: Yim et al. first reported the direct production of 1,4-BDO from glucose by using Escherichia coli strains [8]. 1,4-BDO can be also produced through the chemical process of hydrogenation of biomass-derived succinic acid [12]. 1,3-BDO can be produced from glucose using Escherichia coli [13,14]. 1,3-BDO can be also produced from 4-hydroxy-2-butanone, which is derived from biomass-derived levulinic acid, through microbial fermentation $[15,16]$. The biomass-derived BDOs can be utilized to produce chemicals such as 1,3-butadiene (BD), 3-buten-1-ol (3B1ol), tetrahydrofuran (THF), etc., which are summarized in recent reviews [17-20].

The direct production of BD from BDOs has been reported [21-26]. Phosphate catalysts are effective for the BD production from 2,3-BDO [21,22]. Acidic catalysts such as zeolites and mesoporous 
solid acids are active for the BD formation from 1,3-BDO [23-26] while propylene is produced as a major by-product. In our pioneering research, it has been found that 1,4-BDO is preferentially dehydrated to $3 \mathrm{~B} 1 \mathrm{ol}$ in the vapor phase over $\mathrm{ZrO}_{2}$ catalysts [27,28]. Pure rare earth oxides such as $\mathrm{CeO}_{2}, \mathrm{Er}_{2} \mathrm{O}_{3}$, and $\mathrm{Yb}_{2} \mathrm{O}_{3}$ are also active for the reaction and more selective to $3 \mathrm{~B} 1$ ol than $\mathrm{ZrO}_{2}$ catalysts $[17,29,30]$. Zhang et al. reported an active $\mathrm{CaO}-\mathrm{ZrO}_{2}$ acid-base catalyst for the dehydration of 1,4-BDO [31]. $\mathrm{ZrO}_{2}$-supported $\mathrm{Yb}_{2} \mathrm{O}_{3}$ and $\mathrm{CaO}$ also show high selectivity to 3B1ol [32,33]. We recently investigated the catalytic dehydration of 1,4- and 1,3-BDO over yttria-stabilized tetragonal zirconia (YSZ) catalysts [34]. In the dehydration of 1,4-BDO, a crystalline $\mathrm{YSZ}$ with a $\mathrm{Y}_{2} \mathrm{O}_{3}$ content of $3.2 \mathrm{wt} . \%$ exhibits an excellent stable catalytic activity: the highest selectivity to $3 \mathrm{~B} 1 \mathrm{ol}$ of $75.3 \%$ at the 1,4-BDO conversion of $26.1 \%$ is obtained at $325^{\circ} \mathrm{C}$. The YSZ catalyst also shows an excellent catalytic activity in the dehydration of 1,3-BDO: the highest selectivity to unsaturated alcohols (UOLs) such as 3-buten-2-ol (3B2ol) and 2-buten-1-ol (2B1ol) over $98 \%$ is attained at a conversion of $66 \%$.

We have reported an excellent $\mathrm{Yb}_{2} \mathrm{Zr}_{2} \mathrm{O}_{7}$ catalyst with high crystalline of oxygen-defected fluorite for the vapor-phase dehydration of 1,3-BDO to produce UOLs [35]. The sample prepared through a hydrothermal (HT) process in an ammonia media is confirmed to be oxygen-defected type cubic fluorite, $\mathrm{Yb}_{2} \mathrm{Zr}_{2} \mathrm{O}_{7}$, while the as-prepared co-precipitate sample is amorphous. The $\mathrm{Yb}_{2} \mathrm{Zr}_{2} \mathrm{O}_{7}$ maintains a high specific surface area $(S A)$ as ca. $40 \mathrm{~m}^{2} \mathrm{~g}^{-1}$ even after being calcined at temperatures higher than $800{ }^{\circ} \mathrm{C}$, in contrast to the fact that catalysts without $\mathrm{HT}$ are readily sintered at the temperatures. The $\mathrm{Yb}_{2} \mathrm{Zr}_{2} \mathrm{O}_{7}$ calcined at $900{ }^{\circ} \mathrm{C}$ shows the best catalytic performance: 1,3-BDO conversion of $82 \%$ is achieved with the total selectivity to UOLs higher than $95 \%$ at $325^{\circ} \mathrm{C}$. Also, Fang et al. have recently reported that $\mathrm{Ln}_{2} \mathrm{Zr}_{2} \mathrm{O}_{7}$ ( $\mathrm{Ln}=\mathrm{La}, \mathrm{Pr}$, and $\mathrm{Sm}$ ) pyrochlores as well as $\mathrm{Y}_{2} \mathrm{Zr}_{2} \mathrm{O}_{7}$ fluorite show low-temperature activity for the oxidative coupling of methane [36]. Thus, we expected that rare earth zirconate (REZrO) samples including $\mathrm{Yb}_{2} \mathrm{Zr}_{2} \mathrm{O}_{7}$ would have a great possibility as a catalyst to activate glycol compounds and to produce UOLs through selective dehydration of BDOs.

In this study, we focused on the efficient production of UOLs from 1,4-BDO as well as BDO isomers such as 1,3- and 2,3-BDO (Figure 1), and we performed catalyst screening in $16 \mathrm{REZrO}$ samples. In the preliminary screening, we have found out $\mathrm{Y}_{2} \mathrm{Zr}_{2} \mathrm{O}_{7}$ as a promising catalyst in the dehydration of 1,4- and 1,3-BDO to produce 3B1ol and a mixture of 2B1ol and 3B2ol, respectively. Detail reaction conditions that $\mathrm{Y}_{2} \mathrm{Zr}_{2} \mathrm{O}_{7}$ works efficiently in the catalytic dehydration of 1,4-BDO were estimated, and reaction mechanisms for the dehydration of 1,4-BDO over $\mathrm{Y}_{2} \mathrm{Zr}_{2} \mathrm{O}_{7}$ were discussed.

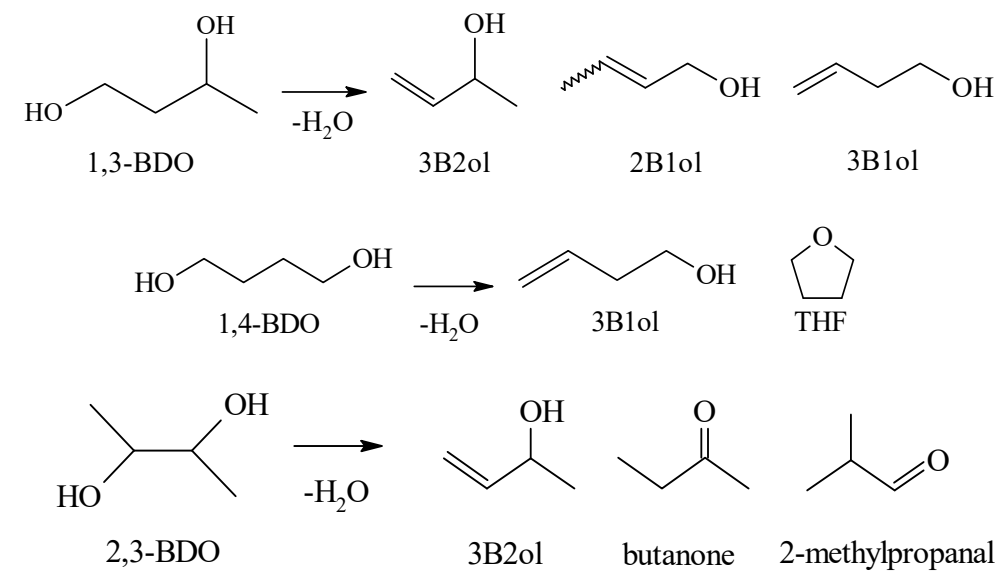

Figure 1. Dehydration of butanediols.

\section{Results}

\subsection{Structural Property of REZrO Catalysts}

Various REZrO samples were prepared by HT treatment using ammonia as a precipitant and a mineralizer. Table 1 lists $S A$ of REZrO samples calcined at $900{ }^{\circ} \mathrm{C}$. The $S A$ values were in the range 
between 16 and $39 \mathrm{~m}^{2} \mathrm{~g}^{-1}$. To confirm that the composition of RE/Zr, XRF analyses of REZrOs were performed, and the results are also summarized in Table 1. A typical $\mathrm{N}_{2}$ adsorption-desorption isotherm of $\mathrm{YZrO}$ is shown in Figure S1. In most of the samples except $\mathrm{LaZrO}, \mathrm{PrZrO}, \mathrm{CeZrO}$, and $\mathrm{ScZrO}$, the ratios of $\mathrm{RE} / \mathrm{Zr}$ were close to 1 or a little larger, and one of the reasons is that $\mathrm{Zr}$ reagent has $\mathrm{Hf}$ as an impurity. This indicates that the REZrO samples have a composition of $\mathrm{RE} / \mathrm{Zr}=\mathrm{ca} .1$. $\mathrm{LaZrO}, \mathrm{PrZrO}, \mathrm{CeZrO}$, and ScZrO samples, however, had a RE/Zr ratio less than 1.

Table 1. Properties of REZrO catalysts calcined at $900{ }^{\circ} \mathrm{C}$.

\begin{tabular}{|c|c|c|c|c|c|}
\hline Catalyst & $\begin{array}{c}\text { Ionic Radius of } \\
\text { Rare Earth Cation a } \\
\text { (nm) }\end{array}$ & $\begin{array}{l}\text { Average Ionic } \\
\text { Radius, } R^{b} \\
\text { (nm) }\end{array}$ & $S A^{\mathrm{c}}\left(\mathrm{m}^{2} \mathrm{~g}^{-1}\right)$ & $\begin{array}{l}\text { Molar Ratio of } \\
\text { RE/Zr/Hf }{ }^{d}\end{array}$ & $\begin{array}{l}\text { Ratio of } \\
\mathrm{RE} / \mathrm{Zr} \mathrm{d}\end{array}$ \\
\hline $\mathrm{LaZrO}$ & 0.1032 & 0.0936 & 16 & 43.3/56.1/0.6 & 0.77 \\
\hline PrZrO & 0.0990 & 0.0915 & 29 & $45.1 / 54.0 / 0.9$ & 0.84 \\
\hline $\mathrm{NdZrO}$ & 0.0983 & 0.09115 & 25 & $52.8 / 46.6 / 0.6$ & 1.13 \\
\hline CeZrO & 0.0970 & 0.0905 & 30 & 47.1/52.3.0.6 & 0.90 \\
\hline $\mathrm{SmZrO}$ & 0.0958 & 0.0899 & 32 & $52.9 / 46.7 / 0.4$ & 1.13 \\
\hline EuZrO & 0.0947 & 0.08935 & 35 & $51.0 / 48.4 / 0.6$ & 1.05 \\
\hline $\mathrm{GdZrO}$ & 0.0938 & 0.0889 & 35 & $52.2 / 47.1 / 0.7$ & 1.11 \\
\hline $\mathrm{TbZrO}$ & 0.0923 & 0.08815 & 34 & $51.8 / 47.6 / 0.6$ & 1.09 \\
\hline DyZrO & 0.0912 & 0.0876 & 32 & $53.2 / 46.2 / 0.6$ & 1.15 \\
\hline $\mathrm{HoZrO}$ & 0.0901 & 0.08705 & 30 & $53.5 / 45.9 / 0.6$ & 1.17 \\
\hline $\mathrm{YZrO}$ & 0.0900 & 0.0870 & 36 & $51.2 / 48.0 / 0.8$ & 1.07 \\
\hline ErZrO & 0.0890 & 0.0865 & 30 & $54.1 / 45.5 / 0.4$ & 1.19 \\
\hline $\mathrm{TmZrO}$ & 0.0880 & 0.0860 & 39 & $53.4 / 46.2 / 0.4$ & 1.16 \\
\hline $\mathrm{YbZrO}$ & 0.0868 & 0.0854 & 27 & $55.0 / 44.6 / 0.4$ & 1.23 \\
\hline $\mathrm{LuZrO}$ & 0.0861 & 0.08505 & 26 & $52.8 / 47.0 / 0.2$ & 1.12 \\
\hline $\mathrm{ScZrO}$ & 0.0745 & 0.07925 & 23 & $27.2 / 71.8 / 1.0$ & 0.38 \\
\hline
\end{tabular}

Figure 2 depicts continuous scanning XRD patterns of 16 REZrO samples prepared through $\mathrm{HT}$ process using ammonia followed by calcination at $900^{\circ} \mathrm{C}$, where $\mathrm{RE}=\mathrm{La}, \mathrm{Ce}, \mathrm{Pr}, \mathrm{Nd}, \mathrm{Sm}, \mathrm{Eu}$, $\mathrm{Gd}, \mathrm{Tb}, \mathrm{Dy}, \mathrm{Ho}, \mathrm{Y}, \mathrm{Er}, \mathrm{Tm}, \mathrm{Yb}, \mathrm{Lu}$, and Sc. In the zirconates of light rare earth such as $\mathrm{La}, \mathrm{Ce}, \mathrm{Pr}$, $\mathrm{Nd}, \mathrm{Sm}$, and $\mathrm{Eu}$ together with $\mathrm{GdZrO}$, the samples were composed of a zirconate and a separated rare earth oxide. For example, the XRD pattern of $\mathrm{CeZrO}$ fitted with the patterns of tetragonal $\mathrm{Zr}_{0.88} \mathrm{Ce}_{0.12} \mathrm{O}_{2}$ (PDF 01-082-1398, P4 $/ n m c$, No. 137) and cubic fluorite-type $\mathrm{Ce}_{0.91} \mathrm{Zr}_{0.0 .9} \mathrm{O}_{2}$ (PDF 01-075-9496, Fm-3m, No. 225) phases, and EuZrO had two phases such as cubic defect fluorite-type $\mathrm{Eu}_{2} \mathrm{Zr}_{2} \mathrm{O}_{7}$ (PDF 01-078-1292, Fm-3m, No. 225) and cubic bixbyite $\mathrm{Eu}_{2} \mathrm{O}_{3}$ (PDF 01-073-6281, I2 ${ }_{1}$ 3, No. 199). In addition, no monoclinic $\mathrm{ZrO}_{2}$ phase was observed in the $\mathrm{REZrO}$ samples, whereas pure $\mathrm{ZrO}_{2}$ prepared in the $\mathrm{HT}$ process without rare earth elements has a monoclinic structure [34]. Although $\mathrm{La}_{2} \mathrm{O}_{3}-\mathrm{ZrO}_{2}, \mathrm{Nd}_{2} \mathrm{O}_{3}-\mathrm{ZrO}_{2}$, and $\mathrm{Sm}_{2} \mathrm{O}_{3}-\mathrm{ZrO}_{2}$ prepared in $\mathrm{HT}$ process using $\mathrm{KOH}$ as a mineralizer are pyrochlore-type $\mathrm{RE}_{2} \mathrm{Zr}_{2} \mathrm{O}_{7}$ ( $F d-3 m$, No. 227), for example, $\mathrm{La}_{2} \mathrm{Zr}_{2} \mathrm{O}_{7}$ (PDF 01-070-5602) and $\mathrm{Sm}_{2} \mathrm{Zr}_{2} \mathrm{O}_{7}$ (PDF 00-024-1012) [35], LaZrO, NdZrO, and SmZrO were composed of different phases in the present paper using ammonia as a mineralizer. In contrast to the light rare earth zirconates, REZrOs of heavy rare earth such as TbZrO, DyZrO, HoZrO, YZrO, ErZrO, TmZrO, YbZrO, and LuZrO were composed of a single phase of zirconate, cubic fluorite-type $\mathrm{RE}_{2} \mathrm{Zr}_{2} \mathrm{O}_{7}$ such as $\mathrm{Dy}_{2} \mathrm{Zr}_{2} \mathrm{O}_{7}$ (PDF 01-078-1293), $\mathrm{Ho}_{2} \mathrm{Zr}_{2} \mathrm{O}_{7}$ (PDF 01-078-1294), $\mathrm{Er}_{2} \mathrm{Zr}_{2} \mathrm{O}_{7}$ (PDF 01-078-1299), and $\mathrm{Yb}_{2} \mathrm{Zr}_{2} \mathrm{O}_{7}$ (PDF 01-078-1300). However, $\mathrm{YZrO}$ was not assigned; both pyrochlore-type (PDF 01-074-9311) and fluorite-type $\mathrm{Y}_{2} \mathrm{Zr}_{2} \mathrm{O}_{7}$ (PDF 01-081-8080) were possible, as shown in Figure S2. To confirm the structure of $\mathrm{YZrO}$, Rietveld analysis was performed in Section 2.3. Among the REZrOs, the ScZrO sample has a rhombohedral structure, $\mathrm{Zr}_{3} \mathrm{Sc}_{4} \mathrm{O}_{12}$ (PDF 01-071-1022, R-3, No. 148). The XRD results indicate that the ScZrO sample has Sc-rich composition. 


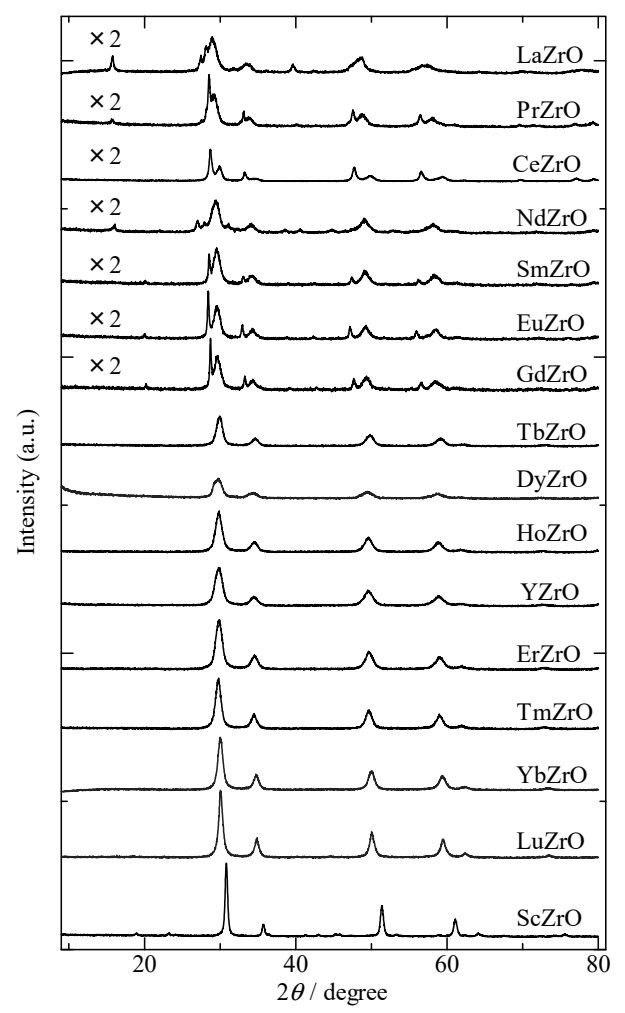

Figure 2. XRD patterns of REZrO samples calcined at $900{ }^{\circ} \mathrm{C}$.

\subsection{Dehydration of Different BDOs over Various REZrO Catalysts}

The dehydration of three BDOs such as 1,4-, 1,3-, and 2,3-BDO was performed over REZrO catalysts at a reaction temperature of $325^{\circ} \mathrm{C}$ and a space time, $W / F$, of $0.31 \mathrm{~h}$ where $W$ and $F$ are the catalyst weight $(\mathrm{g})$ and the flow rate of $\mathrm{BDO}\left(\mathrm{g} \mathrm{h}^{-1}\right)$, respectively. Table 2 shows the results in the dehydration of 1,4-BDO over 16 REZrO catalysts calcined at $900{ }^{\circ} \mathrm{C}$. Six REZrOs such as LaZrO, PrZrO, NdZrO, CeZrO, SmZrO, and ScZrO showed low conversions of 1,4-BDO below 40\% with the selectivity to $3 \mathrm{~B} 1$ ol lower than $66 \%$. Over $\mathrm{LaZrO}, \mathrm{NdZrO}$, and $\mathrm{ScZrO}$, THF was the major product. In contrast, the other ten REZrO catalysts showed the 1,4-BDO conversions higher than 50\% with the 3B1ol selectivity over 75\%. Among the REZrOs, the selectivity to the total of 3B1ol, 2B1ol, and BD, which maintained a straight $\mathrm{C} 4$ carbon chain structure, exceeded $90 \%$ over $\mathrm{DyZrO}, \mathrm{YZrO}$, and ErZrO. In particular, $\mathrm{YZrO}$ showed the highest conversion of $77.6 \%$ as well as the highest $3 \mathrm{~B} 1 \mathrm{ol}$ selectivity of $87.7 \%$. It was confirmed that the catalytic activity of $\mathrm{YZrO}$ was higher than the most active $\mathrm{CaO} / \mathrm{ZrO}_{2}$ catalyst that had been ever reported [33].

Table 3 shows the comparison of reactivity of different BDOs in the dehydration of 1,4-, 1,3-, and 2,3-BDO over several REZrO catalysts calcined at $900^{\circ} \mathrm{C}$ under the same reaction conditions as those in Table 2. In the dehydration of 1,3-BDO over 6 selected REZrO catalysts such as $\mathrm{LaZrO}, \mathrm{CeZrO}, \mathrm{YZrO}$, $\mathrm{YbZrO}, \mathrm{LuZrO}$, and $\mathrm{ScZrO}, \mathrm{YZrO}$ and $\mathrm{YbZrO}$ catalysts showed the 1,3-BDO conversions higher than $89 \%$ whereas $\mathrm{LaZrO}$ and $\mathrm{ScZrO}$ showed low conversions below 50\%. The catalysts had high selectivity to UOLs over $80 \%$. The sum of selectivity to UOLs and BD exceeded $94 \%$, except LaZrO. In particular, over $\mathrm{YZrO}, \mathrm{YbZrO}$, and $\mathrm{LuZrO}$, the sum of selectivity to UOLs and BD exceeded $97 \%$. In the same way as 1,4-BDO, YZrO showed the highest 1,3-BDO conversion of $93.9 \%$ with high UOLs selectivity of $90.2 \%$, while the selectivity to $\mathrm{BD}$ was the highest.

In the dehydration of 2,3-BDO over several REZrO catalysts calcined at $900{ }^{\circ} \mathrm{C}$ (Table 3), under the same reaction conditions, the REZrO catalysts showed 2,3-BDO conversions lower than $20 \%$ with the selectivity to $3 \mathrm{~B} 2 \mathrm{ol}$ at most $50 \%$. Unfortunately, the catalytic activity of $\mathrm{REZrO}$ as well as $\mathrm{YZrO}$ is inferior to the catalysts such as $\mathrm{ZrO}_{2}$ and $\mathrm{Sc}_{2} \mathrm{O}_{3}$ previously reported in the references [38,39]. Thus, in the catalyst screening, it is concluded that the $\mathrm{REZrO}$ catalysts, especially $\mathrm{YZrO}$, are active for the 
vapor-phase dehydration of 1,4- and 1,3-BDO, but they are not suitable for the activation of 2,3-BDO. In each REZrO catalyst, the highest UOLs yield was obtained in the dehydration of 1,3-BDO and the lowest one in 2,3-BDO. Therefore, the reactivity order of BDOs over REZrO catalysts was 1,3-BDO > 1,4-BDO > 2,3-BDO. Because $\mathrm{YZrO}$ showed the highest 1,4-BDO conversion and the highest 3B1ol selectivity, we investigated the $\mathrm{YZrO}$ catalyst in detail in the following sections.

Table 2. Dehydration of 1,4-BDO over REZrO catalysts calcined at $900{ }^{\circ} \mathrm{C}$.

\begin{tabular}{|c|c|c|c|c|c|c|c|c|}
\hline \multirow{2}{*}{ Catalyst } & \multirow{2}{*}{$\begin{array}{c}\text { Conversion } \\
(\%)\end{array}$} & \multicolumn{7}{|c|}{ Selectivity (mol\%) } \\
\hline & & 3B1ol & 2B1ol & UOLs & BD & THF & GBL & Others \\
\hline $\mathrm{LaZrO}$ & 29.1 & 6.1 & 0.5 & 6.6 & 0.0 & 88.4 & 3.1 & 1.9 \\
\hline PrZrO & 25.2 & 61.7 & 1.5 & 63.2 & 0.0 & 32.7 & 2.5 & 1.6 \\
\hline $\mathrm{NdZrO}$ & 37.7 & 32.4 & 0.8 & 33.2 & 0.0 & 63.7 & 0.5 & 2.6 \\
\hline $\mathrm{CeZrO}$ & 24.7 & 60.8 & 5.6 & 66.4 & 0.0 & 24.9 & 5.6 & 3.1 \\
\hline $\mathrm{SmZrO}$ & 37.3 & 65.8 & 1.3 & 67.1 & 0.1 & 30.8 & 0.9 & 1.1 \\
\hline EuZrO & 52.8 & 82.6 & 2.8 & 85.4 & 0.8 & 10.8 & 2.2 & 0.8 \\
\hline $\mathrm{GdZrO}$ & 68.5 & 81.5 & 1.9 & 83.4 & 0.5 & 15.3 & 0.4 & 0.4 \\
\hline $\mathrm{TbZrO}$ & 52.4 & 76.1 & 1.1 & 77.2 & 0.6 & 21.0 & 0.9 & 0.3 \\
\hline DyZrO & 69.4 & 86.5 & 2.7 & 89.2 & 1.6 & 7.9 & 0.4 & 0.9 \\
\hline $\mathrm{HoZrO}$ & 51.2 & 82.6 & 1.7 & 84.3 & 0.8 & 13.3 & 0.7 & 0.9 \\
\hline $\mathrm{YZrO}$ & 77.6 & 87.7 & 2.8 & 90.5 & 1.2 & 7.5 & 0.6 & 0.2 \\
\hline ErZrO & 64.4 & 85.8 & 4.0 & 89.8 & 1.9 & 7.4 & 0.3 & 0.6 \\
\hline $\mathrm{TmZrO}$ & 55.9 & 82.8 & 1.3 & 84.1 & 1.1 & 13.3 & 0.3 & 1.2 \\
\hline $\mathrm{YbZrO}$ & 61.3 & 84.8 & 2.2 & 87.0 & 0.8 & 11.5 & 0.3 & 0.4 \\
\hline $\mathrm{LuZrO}$ & 51.2 & 84.3 & 2.0 & 86.3 & 2.6 & 9.0 & 0.3 & 1.8 \\
\hline $\mathrm{ScZrO}$ & 35.5 & 30.0 & 0.1 & 30.1 & 0.0 & 68.9 & 0.3 & 0.7 \\
\hline
\end{tabular}

Conversion and selectivity are averaged at time on stream (TOS) between $1-5 \mathrm{~h}$. Reaction conditions: temperature, $325^{\circ} \mathrm{C} ; W / F, 0.31 \mathrm{~h}$; catalyst weight, $0.50 \mathrm{~g} ; \mathrm{N}_{2}$ carrier gas flow rate, $30 \mathrm{~cm}^{3} \mathrm{~min}^{-1}$. 3B1ol, 3-buten-1-ol; 2B1ol, 2-buten-1-ol; $\mathrm{UOLs}=3 \mathrm{~B} 1 \mathrm{ol}+2 \mathrm{~B} 1 \mathrm{ol} ; \mathrm{BD}, 1,3$-butadiene; THF, tetrahydrofuran; $\mathrm{GBL}, \gamma$-butyrolactone. Others include ethanol, 1-butanol, and some unidentified products.

Table 3. Comparison in the dehydration of 1,3-, 1,4- and 2,3-BDO over REZrO calcined at $900{ }^{\circ} \mathrm{C}$.

\begin{tabular}{|c|c|c|c|c|c|c|c|c|c|c|c|}
\hline \multirow{2}{*}{ Catalyst } & \multirow{2}{*}{ Reactant } & \multirow{2}{*}{$\begin{array}{c}\text { Conv. } \\
(\%)\end{array}$} & \multicolumn{9}{|c|}{ Selectivity (mol\%) } \\
\hline & & & 3B2ol & 3B1ol & 2B1ol & UOLs & BD & MEK & THF & $3 \mathrm{H} 2 \mathrm{BO}$ & Others \\
\hline \multirow{3}{*}{$\mathrm{LaZrO}$} & 1,3-BDO & 40.2 & 44.9 & 1.2 & 35.1 & 81.2 & 1.7 & 6.8 & - & - & $10.3^{\mathrm{a}}$ \\
\hline & 1,4-BDO & 29.1 & - & 6.1 & 0.5 & 6.6 & 0 & - & 88.4 & - & $5.0^{b}$ \\
\hline & 2,3-BDO & 4.8 & 28.3 & - & - & 28.3 & 0 & 16.1 & - & 37.1 & $18.5^{c}$ \\
\hline \multirow{3}{*}{$\mathrm{CeZrO}$} & 1,3-BDO & 64.7 & 55.8 & 1.0 & 35.1 & 91.9 & 2.8 & 0.7 & - & - & $4.6^{\mathrm{a}}$ \\
\hline & 1,4-BDO & 24.7 & - & 60.8 & 5.6 & 66.4 & 0 & - & 24.9 & - & $8.7^{b}$ \\
\hline & 2,3-BDO & 6.6 & 15.4 & - & - & 15.4 & 0 & 29.4 & - & 33.4 & $21.8^{\mathrm{c}}$ \\
\hline \multirow{3}{*}{$\mathrm{YZrO}$} & 1,3-BDO & 93.9 & 52.1 & 1.3 & 36.8 & 90.2 & 7.2 & 0.2 & - & - & $2.4^{\mathrm{a}}$ \\
\hline & 1,4-BDO & 77.6 & - & 87.7 & 2.8 & 90.5 & 1.2 & - & 7.5 & - & $0.8^{b}$ \\
\hline & 2,3-BDO & 17.0 & 30.3 & - & - & 30.3 & 0 & 10.9 & - & 26.8 & $32.0^{\mathrm{c}}$ \\
\hline \multirow{3}{*}{$\mathrm{YbZrO}$} & 1,3-BDO & 89.8 & 53.9 & 1.4 & 40.9 & 96.2 & 1.0 & 1.0 & - & - & $1.8^{\mathrm{a}}$ \\
\hline & 1,4-BDO & 61.3 & - & 84.8 & 2.2 & 87.0 & 0.8 & - & 11.5 & - & $0.7^{b}$ \\
\hline & 2,3-BDO & 12.2 & 46.9 & - & - & 46.9 & 0 & 7.3 & - & 28.4 & $17.4^{\mathrm{c}}$ \\
\hline \multirow{3}{*}{ LuZrO } & 1,3-BDO & 83.0 & 50.8 & 1.7 & 42.9 & 95.4 & 2.0 & 0.9 & - & - & $1.7^{\mathrm{a}}$ \\
\hline & 1,4-BDO & 51.2 & - & 84.3 & 2.0 & 86.3 & 2.6 & - & 9.0 & - & $2.1^{b}$ \\
\hline & 2,3-BDO & 11.3 & 50.8 & - & - & 50.8 & 0 & 10.1 & - & 24.2 & $14.9^{\mathrm{c}}$ \\
\hline \multirow{3}{*}{$\mathrm{ScZrO}$} & 1,3-BDO & 20.6 & 43.1 & 12.7 & 39.7 & 95.5 & 0 & 1.4 & - & - & $3.1^{\mathrm{a}}$ \\
\hline & 1,4-BDO & 35.5 & - & 30.0 & 0.1 & 30.1 & 0 & - & 68.9 & - & $1.0^{\mathrm{b}}$ \\
\hline & 2,3-BDO & 18.4 & 47.4 & - & - & 47.4 & 0 & 18.7 & - & 16.0 & $17.9^{\mathrm{c}}$ \\
\hline
\end{tabular}

Reaction conditions are the same as those in Table 2. 3B2ol, 3-buten-2-ol; 3B1ol, 3-buten-1-ol; 2B1ol, 2-buten-1-ol; UOLs $=3 \mathrm{~B} 2 \mathrm{ol}+3 \mathrm{~B} 1 \mathrm{ol}+2 \mathrm{~B} 1 \mathrm{ol} ; \mathrm{BD}, 1$,3-butadiene; MEK, butanone; THF, tetrahydrofuran; 3H2BO, 3-hydroxy-2-butanone. a Others include ethanol, acetone, 1-butanol, 3-buten-2-one, etc. ${ }^{\mathrm{b}}$ Others include $\gamma$-butyrolactone, 1-butanol, ethanol, etc. ${ }^{c}$ Others include 2-methylpropanal, 2-methyl-1-propanol, 2-butanol, ethanol, acetone, etc. 
2.3. Effect of Calcination Temperature on the Structure of $\mathrm{YZrO}$ Catalysts and Catalytic Activity in the Dehydration of 1,4-BDO

Table 4 lists $S A$ of $Y Z r O$ samples calcined at different temperatures. The $S A$ value was decreased when the raising calcination temperature from 91 to $16 \mathrm{~m}^{2} \mathrm{~g}^{-1}$ at the temperature range between 600 and $1050{ }^{\circ} \mathrm{C}$. The particle size calculated from the $S A, D_{\mathrm{BET}}$, is also summarized in Table 4 . Figure 3 shows continuous scanning XRD analysis of $\mathrm{YZrO}$ samples calcined at different temperatures. The as-prepared sample was crystallized during the HT process. All the samples calcined at $600-1050{ }^{\circ} \mathrm{C}$ had a major diffraction peak at 29.9 degree. The crystallite size, $D_{\mathrm{XRD}}$, which was estimated from of the major diffraction peak using the Scherrer equation, is also summarized. The $D_{\mathrm{XRD}}$ value was simply increased when raising the calcination temperature. There is a significant difference between the crystallite size and the particle size: $D_{\mathrm{XRD}}$ was much smaller than $D_{\mathrm{BET}}$. To confirm the morphology of catalysts calcined at different temperatures.

Table 4. Physical properties of YZrO calcined at different temperatures.

\begin{tabular}{ccccc}
\hline $\begin{array}{c}\text { Calcination } \\
\left({ }^{\circ} \mathbf{C}\right)\end{array}$ & $\begin{array}{c}\text { SA } \\
\left(\mathbf{m}^{\mathbf{2}} \mathbf{g}^{\mathbf{- 1})}\right.\end{array}$ & $\begin{array}{c}\text { FWHM at } \mathbf{2} \boldsymbol{\theta}=\mathbf{2 9 . 9 ^ { \circ }} \\
\mathbf{( d e g r e e )}\end{array}$ & $\begin{array}{c}\text { Particle Size, } \\
\mathbf{D}_{\text {BET }}(\mathbf{n m})\end{array}$ & $\begin{array}{c}\text { Crystallite Size, } \\
\boldsymbol{D}_{\text {XRD }}(\mathbf{n m})\end{array}$ \\
\hline 600 & 91 & 1.792 & 12 & 4.6 \\
800 & 51 & 1.439 & 22 & 5.7 \\
900 & 36 & 1.242 & 31 & 6.6 \\
1000 & 19 & 0.670 & 58 & 12 \\
1050 & 16 & 0.543 & 70 & 15 \\
\hline
\end{tabular}

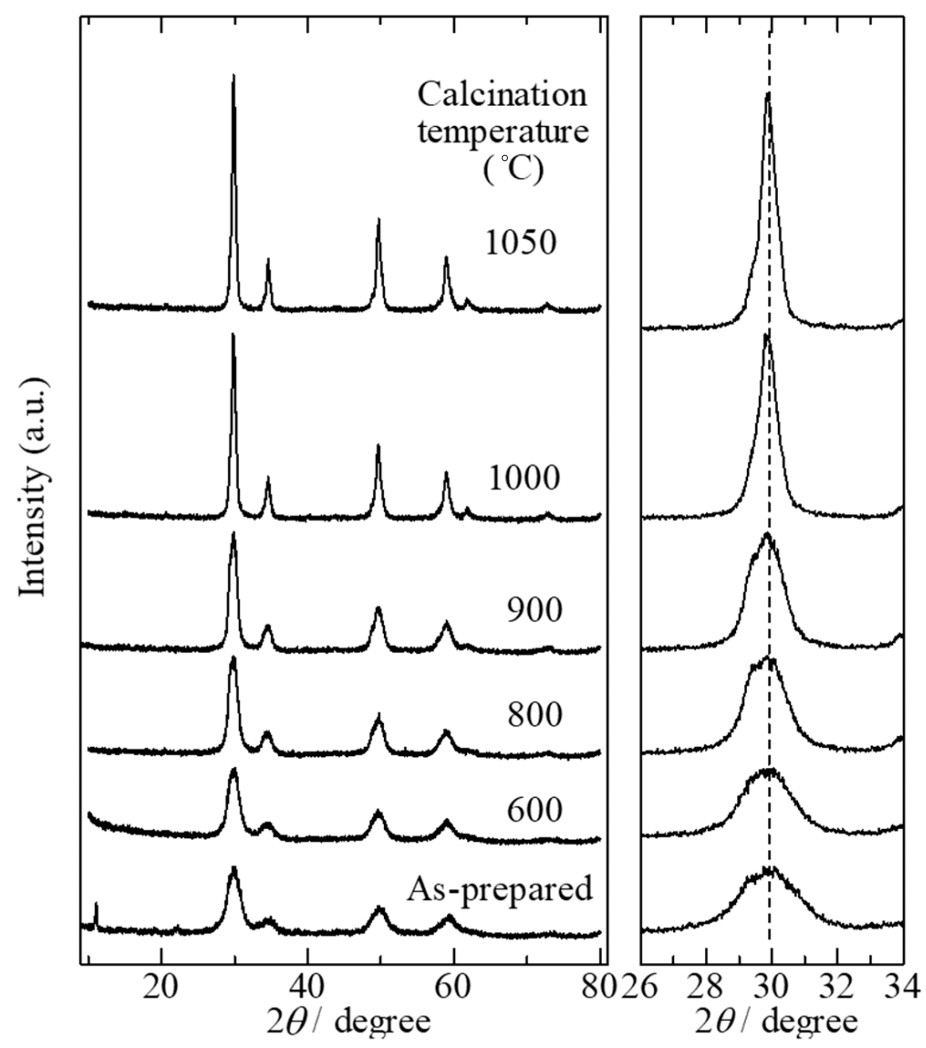

Figure 3. Continuous scanning XRD patterns of $\mathrm{YZrO}$.

For YZrO, we observed the FE-SEM image (Figure 4). The SEM image clearly shows that the $\mathrm{YZrO}$ sample calcined at $900{ }^{\circ} \mathrm{C}$ is composed of agglomerates of particles with the size of $30-50 \mathrm{~nm}$, which is consistent with the $D_{\mathrm{BET}}$ value of $31 \mathrm{~nm}$ rather than the $D_{\mathrm{XRD}}$ of $6.6 \mathrm{~nm}$. This indicates that the particles shown in the SEM image are non-porous primary particles. 


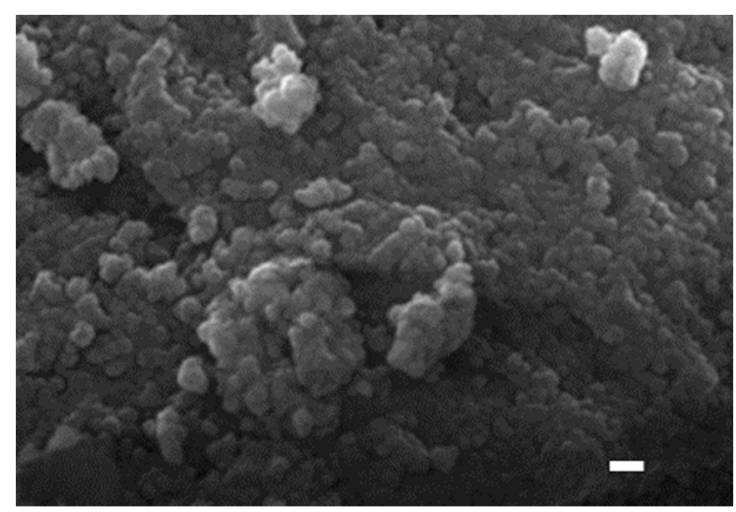

Figure 4. FE-SEM image of $\mathrm{YZrO}$ calcined at $900{ }^{\circ} \mathrm{C}$. A scale bar in the photo indicates $100 \mathrm{~nm}$.

Even at a high calcination temperature of $1050{ }^{\circ} \mathrm{C}$, the result of Rietveld analysis was not satisfied within the fitting errors because of low diffraction intensity. Figure 5 shows the step-scanning XRD pattern of $\mathrm{YZrO}$ sample calcined at $1200^{\circ} \mathrm{C}$. We confirmed diffraction angles are the same between $\mathrm{YZrO}$ calcined at 1050 and $1200^{\circ} \mathrm{C}$. Thus, Rietveld analysis was performed in a YZrO sample calcined at $1200{ }^{\circ} \mathrm{C}$ to refine the structure parameter (Figure 5). We confirmed that the sample was composed of defect fluorite-type $\mathrm{Y}_{2} \mathrm{Zr}_{2} \mathrm{O}_{7}$, but not pyrochlore. Table 5 lists the refined structure parameters of $\mathrm{Y}_{2} \mathrm{Zr}_{2} \mathrm{O}_{7}$

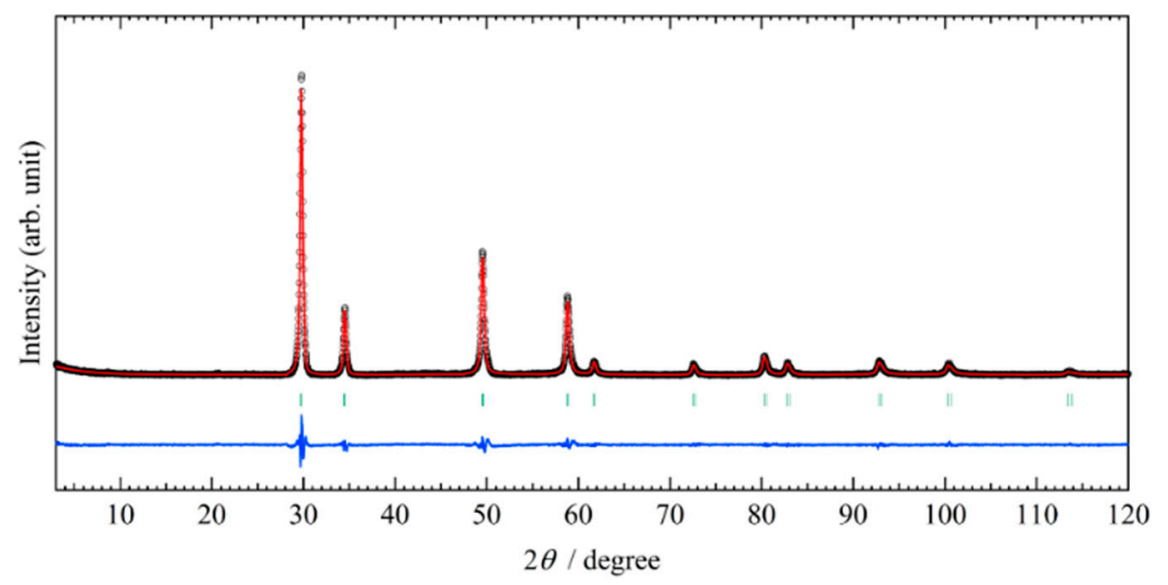

Figure 5. Step-scanning XRD pattern of $\mathrm{YZrO}$ calcined at $1200^{\circ} \mathrm{C}$ with calculated XRD pattern.

Table 5. Refined structure parameters of $\mathrm{Y}_{2} \mathrm{Zr}_{2} \mathrm{O}_{7}$ and $\mathrm{YZrO}$ calcined at $1200{ }^{\circ} \mathrm{C}$.

\begin{tabular}{cccc}
\hline Sample & $\mathbf{Y}_{2} \mathbf{Z r}_{2} \mathbf{O}_{7}$ \\
\hline Space Group & $\boldsymbol{F m}-\mathbf{3 m}^{\mathbf{a}}$ \\
\hline$a(\AA)$ & 5.19878 & $B(\mathrm{Y})$ & 1.81615 \\
$\alpha$ (degree) & 90.0000 & $B(\mathrm{Zr})$ & 1.77582 \\
$\beta$ (degree) & 90.0000 & $B(\mathrm{O})$ & 3.46843 \\
$\gamma$ (degree) & 90.0000 & $R_{\mathrm{wp}}(\%)$ & $12.229 \%$ \\
$g(\mathrm{Y}){ }^{\mathrm{b}}$ & 0.5000 & $R_{\mathrm{B}}(\%)$ & $2.039 \%$ \\
$g(\mathrm{Zr})^{\mathrm{b}}$ & 0.5000 & $R_{\mathrm{F}}(\%)$ & $1.593 \%$ \\
$g(\mathrm{O})^{\mathrm{b}}$ & 0.8750 & $S$ & 1.3891 \\
\hline
\end{tabular}

g: occupancy; $B$ : isotropic atomic displacement parameter. ${ }^{a}$ Atomic sites: $(\mathrm{Y}, \mathrm{Zr}) 4 a(0,0,0)$ and $\mathrm{O} 8 c(1 / 4,1 / 4,1 / 4)$.

${ }^{b}$ Fixed during the refinement.

Black points and red lines represent observed and calculated patterns, respectively. Green vertical marks indicate the Bragg reflection positions of defected-fluorite $\mathrm{Y}_{2} \mathrm{Zr}_{2} \mathrm{O}_{7}$ phase. Blue line at the 
bottom shows the difference between the observed and calculated patterns (For interpretation of the references to color in this figure legend, the reader is referred to the web version of this article).

Figure 6 shows the effect of calcination temperature of $\mathrm{YZrO}$ on the conversion of 1,4-BDO, and the numerical data are located in Table S1. The 1,4-BDO conversion was maximized at $900{ }^{\circ} \mathrm{C}$, and the selectivity to 3B1ol increased with raising the calcination temperature. The selectivity to THF showed an opposite trend to the selectivity to 3B1ol. The conversion, which increases with raising calcination temperature, is in reverse proportion to specific surface area at the range between 600 and $900{ }^{\circ} \mathrm{C}$.

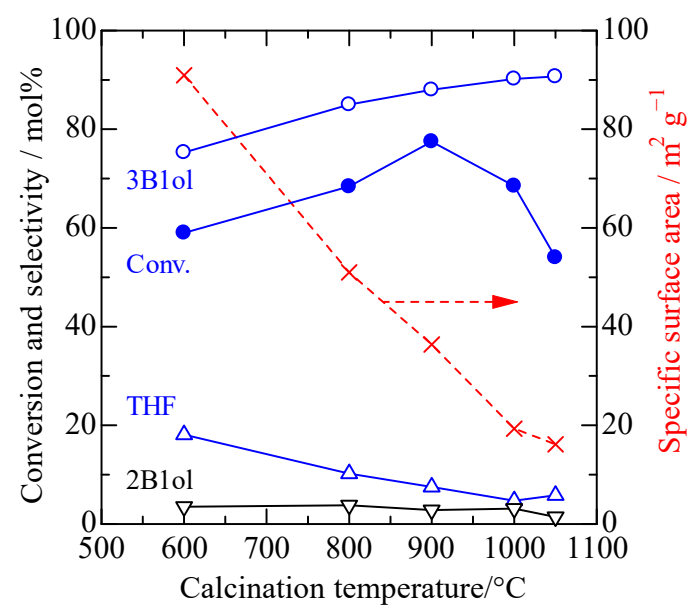

Figure 6. Effect of calcination temperature of YZrO catalyst on the dehydration of 1,4-BDO and SA.

\subsection{Catalytic Dehydration of 1,4-BDO over $\mathrm{YZrO}$ Calcined at $900^{\circ} \mathrm{C}$ under Different Reaction Conditions}

Figure 7 shows the change in conversion with different space time at $325^{\circ} \mathrm{C}$. The space time, $W / F$, was controlled by the variation of $W$ at a constant $F$, where the numerical data are listed in Table S2. The 1,4-BDO conversion simply increased with increasing the space time. At a $W / F=0.94 \mathrm{~h}$, $99.4 \%$ of the 1,4-BDO conversion was attained. The selectivity to 3B1ol gradually decreased from 87.7 to $77.9 \%$ with the increase in the selectivity to $2 \mathrm{~B} 1 \mathrm{ol}$ and $\mathrm{BD}$, while the sum of selectivity to UOLs and $\mathrm{BD}$ seemed to be constant. This means that both $2 \mathrm{~B} 1 \mathrm{ol}$ and $\mathrm{BD}$ are regarded as the secondary products produced from 3B1ol. The selectivity to THF, however, was almost constant in the variation of W/F. Therefore, 3B1ol and THF are the primary products in the dehydration of 1,4-BDO. In addition, the UOLs formation rate at $325^{\circ} \mathrm{C}$ was almost constant at conversions lower than $80 \%$ (Table S2): the rate is reduced at a $W / F=0.31 \mathrm{~h}$ by $10 \%$ by comparing at $0.19 \mathrm{~h}$. At high conversions near $100 \%$, 2B1ol and BD increased with decreasing 3B1ol (Figure 7 and Table 6).

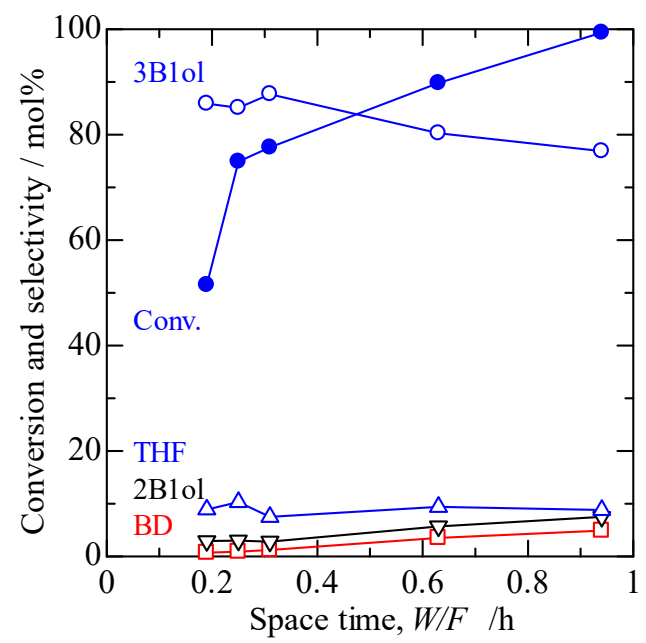

Figure 7. Change in the conversion of 1,4-BDO with space time over $\mathrm{YZrO}$ calcined at $900{ }^{\circ} \mathrm{C}$. 
Table 6. Dehydration of 1,4-BDO over $\mathrm{YZrO}$ at different reaction temperatures.

\begin{tabular}{cccccccccc}
\hline Temperature & Conv. & \multicolumn{7}{c}{ Selectivity (mol\%) } \\
\cline { 3 - 10 }$\left({ }^{\mathbf{C}} \mathbf{C}\right)$ & $\mathbf{( \% )}$ & $\mathbf{3 B 1 0 l}$ & $\mathbf{2 B 1 0 l}$ & UOLs & BD & Propylene & THF & GBL & Others \\
\hline 300 & 25.9 & 84.0 & 1.1 & 85.1 & 0.4 & 0.0 & 12.4 & 0.6 & 1.5 \\
325 & 77.6 & 87.7 & 2.8 & 90.5 & 1.2 & 0.0 & 7.5 & 0.6 & 0.2 \\
350 & 99.8 & 70.2 & 7.1 & 77.3 & 11.5 & 0.0 & 9.9 & 0.2 & 1.1 \\
360 & 100.0 & 53.0 & 10.1 & 63.1 & 22.2 & 0.0 & 11.5 & 0.1 & 3.1 \\
375 & 100.0 & 23.8 & 4.4 & 28.2 & 58.8 & 5.8 & 3.7 & 0.1 & $3.4^{\text {a }}$ \\
\hline
\end{tabular}

The catalyst sample was calcined at $900{ }^{\circ} \mathrm{C}$. Conversion and selectivity were averaged at TOS between $1-5 \mathrm{~h}$. Reaction conditions: $W / F, 0.31 \mathrm{~h}$; catalyst weight, $0.50 \mathrm{~g}$; $\mathrm{N}_{2}$ flow rate, $30 \mathrm{~cm}^{3} \mathrm{~min}^{-1}$. 3B1ol, 3-buten-1-ol; 2B1ol, 2-buten-1-ol; UOLs = 3B1ol + 2B1ol; BD, 1,3-butadiene; THF, tetrahydrofuran; GBL, $\gamma$-butyrolactone. Others include ethanol, 1-butanol, $\mathrm{CO}_{2}$, and some unidentified products. ${ }^{a}$ includes $1.8 \mathrm{~mol} \%$ of $\mathrm{CO}_{2}$.

Table 6 summarized the conversion data at different reaction temperatures in the dehydration of 1,4-BDO over $\mathrm{YZrO}$ calcined at $900{ }^{\circ} \mathrm{C}$. With raising the reaction temperature, the conversion was increased, and the complete conversion was attained at $360^{\circ} \mathrm{C}$. The selectivity to $3 \mathrm{~B} 1 \mathrm{ol}$ was decreased through the maximum at $325^{\circ} \mathrm{C}$ : the selectivity to $3 \mathrm{~B} 1 \mathrm{ol}$ and UOLs was 87.7 and $90.5 \%$, respectively. At a temperature of $350^{\circ} \mathrm{C}$ or higher, $\mathrm{BD}$ was produced together with the production of propylene, which was formed via the decomposition of $3 \mathrm{~B} 1 \mathrm{ol}[40,41]$. The propylene produced at $375^{\circ} \mathrm{C}$ was comparable to that of $\mathrm{CO}_{2}$ : the selectivity to $\mathrm{CO}_{2}$ at $375{ }^{\circ} \mathrm{C}$ was $1.8 \%$, which indicates that a molar ratio of propylene/ $/ \mathrm{CO}_{2}$ is 1.07 .

\subsection{Effect of Carrier Gas on the Catalytic Dehydration of 1,4-BDO over YZrO Calcined at $900{ }^{\circ} \mathrm{C}$}

The effect of carrier gas in the dehydration of 1,4-BDO over $\mathrm{YZrO}$ catalyst was investigated to clarify the role of basic and acidic sites of $\mathrm{YZrO}$ catalyst: either $\mathrm{CO}_{2}, \mathrm{NH}_{3}$, or $\mathrm{H}_{2}$ was adapted as a carrier gas instead of $\mathrm{N}_{2}$ gas. Table 7 shows the effect of carrier gas on the conversion of 1,4-BDO over $\mathrm{YZrO}$ at 325 and $300{ }^{\circ} \mathrm{C}$. In $\mathrm{CO}_{2}$ flow, the conversion, the $3 \mathrm{~B} 1 \mathrm{ol}$ selectivity, and the $3 \mathrm{~B} 1 \mathrm{ol}$ productivity were smaller than those in $\mathrm{N}_{2}$ flow. Thus, $\mathrm{CO}_{2}$ gas could work as a poison of basic sites. In $\mathrm{NH}_{3}$ flow at $325^{\circ} \mathrm{C}$, in contrast, the conversion level and the $3 \mathrm{~B} 1 \mathrm{ol}$ productivity were slightly higher than those in $\mathrm{N}_{2}$ flow: an $\mathrm{NH}_{3}$ seems to act as an accelerator, but not as a poison. It is much clearer, at $300{ }^{\circ} \mathrm{C}$, that $\mathrm{NH}_{3}$ gas accelerates the reaction. $\mathrm{An} \mathrm{NH}_{3}$ gas may act as a base catalyst together with catalyst surface for the abstraction of hydrogen from 1,4-BDO. It is possible that either weakly adsorbed $\mathrm{NH}_{3}$ or gas-phase one may act as a catalyst.

Table 7. Effects of carrier gas on the dehydration of 1,4-BDO over $\mathrm{YZrO}$ calcined at $900{ }^{\circ} \mathrm{C}$.

\begin{tabular}{|c|c|c|c|c|c|c|c|c|c|}
\hline \multirow{2}{*}{$\begin{array}{l}\text { Carrier } \\
\text { Gas }\end{array}$} & \multirow{2}{*}{$\begin{array}{c}\text { Conversion } \\
(\%)\end{array}$} & \multicolumn{7}{|c|}{ Selectivity (mol\%) } & \multirow{2}{*}{$\begin{array}{l}\text { Productivity of 3B1ol } \\
\qquad \mathrm{mol} \mathrm{h}^{-1} \mathrm{~kg}^{-1}\end{array}$} \\
\hline & & 3B1ol & 2B1ol & UOLs & BD & THF & GBL & Others & \\
\hline \multicolumn{10}{|l|}{$\mathrm{T}=325{ }^{\circ} \mathrm{C}$} \\
\hline $\mathrm{N}_{2}$ & 77.6 & 87.7 & 2.8 & 90.5 & 1.2 & 7.5 & 0.6 & 0.2 & 24.2 \\
\hline $\mathrm{CO}_{2}$ & 74.6 & 64.6 & 1.5 & 66.1 & 0.3 & 32.3 & 0.8 & 0.5 & 17.1 \\
\hline $\mathrm{NH}_{3}$ & 81.9 & 85.5 & 6.5 & 92.0 & 0.0 & 6.8 & 0.1 & 1.1 & 24.9 \\
\hline $\mathrm{H}_{2}$ & 87.8 & 86.7 & 3.3 & 90.0 & 1.0 & 8.4 & 0.4 & 0.2 & 27.0 \\
\hline \multicolumn{10}{|l|}{$T=300^{\circ} \mathrm{C}$} \\
\hline $\mathrm{N}_{2}$ & 25.9 & 84.0 & 1.1 & 85.1 & 0.4 & 12.4 & 0.6 & 1.5 & 7.7 \\
\hline $\mathrm{CO}_{2}$ & 19.2 & 60.8 & 1.5 & 62.3 & 0.0 & 34.0 & 1.6 & 2.1 & 4.1 \\
\hline $\mathrm{NH}_{3}$ & 32.3 & 87.6 & 1.5 & 89.1 & 0.0 & 9.9 & 0.2 & 0.7 & 10.1 \\
\hline $\mathrm{N}_{2}\left(\mathrm{NH}_{3}\right)^{\mathrm{a}}$ & 16.0 & 76.6 & 10.3 & 86.9 & 0.0 & 7.8 & 1.5 & 3.8 & 4.4 \\
\hline
\end{tabular}

Conversion and selectivity are averaged at TOS between 1-5 h. Reaction conditions: $T$, reaction temperature; $W / F, 0.31 \mathrm{~h}$; carrier gas flow rate, $30 \mathrm{~cm}^{3} \mathrm{~min}^{-1}$. 3B1ol, 3-buten-1-ol; 2B1ol, 2-buten-1-ol; UOLs = 3B1ol + 2B1ol; $\mathrm{BD}, 1$,3-butadiene; THF, tetrahydrofuran; GBL, $\gamma$-butyrolactone. Others include ethanol, 1-butanol, and some unidentified products. ${ }^{a}$ Prior to the preheating in $\mathrm{N}_{2}$ at $300{ }^{\circ} \mathrm{C}$ for $1 \mathrm{~h}, \mathrm{NH}_{3}$ was flowed at a rate of $30 \mathrm{~cm}^{3} \mathrm{~min}^{-1}$ and $300^{\circ} \mathrm{C}$ for $0.5 \mathrm{~h}$. 
Then, we adopted pre-adsorption of $\mathrm{NH}_{3}$ before the reaction to confirm the above-mentioned hypothesis. In Figure S3, the conversion at TOS of the initial $2 \mathrm{~h}$ was higher than 25\%, which is higher than that in $\mathrm{N}_{2}$, but it reduced to $13 \%$ after TOS of $2 \mathrm{~h}$. This indicates either hydrogen-bonded or weakly adsorbed molecular $\mathrm{NH}_{3}$ acts as a base catalyst, but it removes from the surface during the reaction. Thus, $\mathrm{NH}_{3}$ adsorbed on $\mathrm{YZrO}$ at $300{ }^{\circ} \mathrm{C}$ acted as a poison of acidic sites in $\mathrm{N}_{2}$ flow (Table 7). In the formation of THF, however, the selectivity to THF was preferential in $\mathrm{CO}_{2}$ flow, and it was depressed in $\mathrm{NH}_{3}$ flow at both 325 and $300{ }^{\circ} \mathrm{C}$. In $\mathrm{H}_{2}$ flow, the 1,4-BDO conversion was higher than that in $\mathrm{N}_{2}$ flow at $325^{\circ} \mathrm{C} . \mathrm{H}_{2}$ gas accelerates the formation of $3 \mathrm{~B} 1 \mathrm{ol}$ in the dehydration of 1,4-BDO over YZrO catalyst. The acceleration effect of $\mathrm{H}_{2}$ will be discussed in Section 3.3.

Figure 8 shows the changes in the conversion of 1,4-BDO with time on stream in long run tests. The catalytic activity, i.e., the 1,4-BDO conversion and the selectivity to each product, was stabilized at a conversion of ca. $87 \%$ in $\mathrm{H}_{2}$ flow for $30 \mathrm{~h}$. In $\mathrm{N}_{2}$ flow, however, a gradual decrease in the 1,4-BDO conversion was observed; the conversion was decreased from 79 to $75 \%$ for $30 \mathrm{~h}$. As shown in Table 7, the 1,4-BDO conversion in $\mathrm{N}_{2}$ was lower than that in $\mathrm{H}_{2}$ although the selectivity to 3B1ol was higher. The highest $3 \mathrm{~B} 1 \mathrm{ol}$ productivity of $27.0 \mathrm{~mol} \mathrm{~h}^{-1} \mathrm{~kg}^{-1}$ was obtained in $\mathrm{H}_{2}$ flow, while it was $24.2 \mathrm{~mol} \mathrm{~h}^{-1} \mathrm{~kg}^{-1}$ in $\mathrm{N}_{2}$ flow.

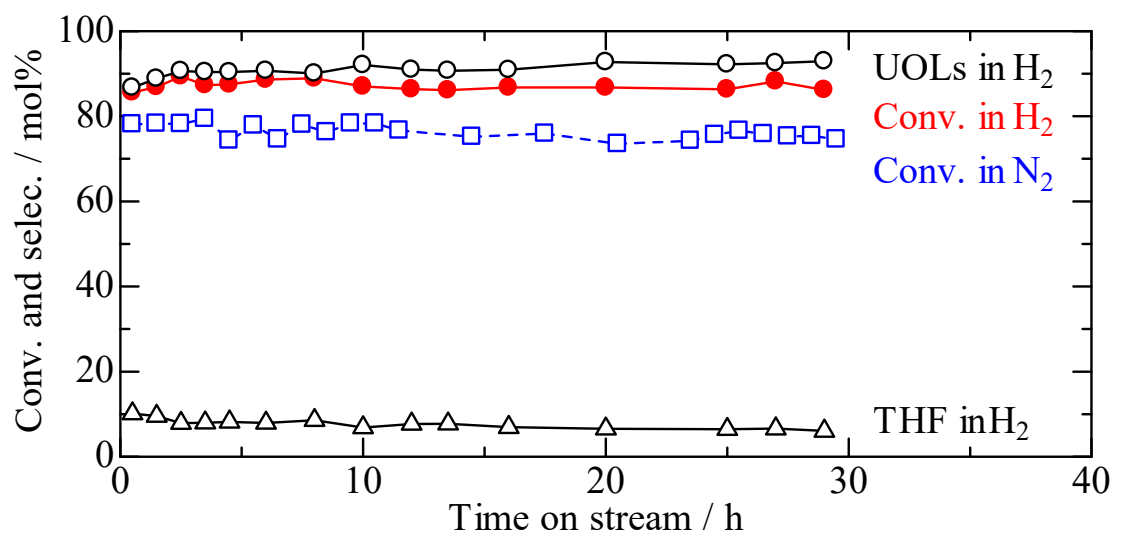

Figure 8. Long-run stability in the conversion of 1,4-BDO over $\mathrm{YZrO}$ calcined at $900{ }^{\circ} \mathrm{C}$. Reaction temperature, $325^{\circ} \mathrm{C}$; carrier gas flow rate, $30 \mathrm{~cm}^{3} \mathrm{~min}^{-1} ; W / F=0.31 \mathrm{~h}$.

\subsection{Acid-base Properties of $\mathrm{YZrO}$ Catalyst Calcined at 600 and $900{ }^{\circ} \mathrm{C}$}

Figure 9 illustrates temperature-programmed desorption (TPD) profiles of adsorbed $\mathrm{NH}_{3}$ and $\mathrm{CO}_{2}$ on $\mathrm{YZrO}$ calcined at 600 and $900{ }^{\circ} \mathrm{C}$. In Figure 9A, the amount of desorbed $\mathrm{CO}_{2}$ from $\mathrm{YZrO}$ calcined at $600{ }^{\circ} \mathrm{C}$ is more than that of $\mathrm{NH}_{3}$. The amounts of acidic and basic sites were calculated to be 0.193 and $0.313 \mathrm{mmol} \mathrm{g}{ }^{-1}$ up to $600^{\circ} \mathrm{C}$, respectively. In contrast, the TPD profiles of $\mathrm{NH}_{3}$ and $\mathrm{CO}_{2}$ adsorbed on $\mathrm{YZrO}$ calcined at $900^{\circ} \mathrm{C}$ were quite similar to each other (Figure $9 \mathrm{~B}$ ): the amounts of acidic and basic sites were calculated to be 0.123 and $0.127 \mathrm{mmol} \mathrm{g}^{-1}$ up to $500^{\circ} \mathrm{C}$, respectively.

Acid strength distributions obtained for both catalysts showed little variations in the low temperature range. In the high temperature range above $400{ }^{\circ} \mathrm{C}$, the reduction of $\mathrm{NH}_{3}$ released during TPD for the sample calcined at $900{ }^{\circ} \mathrm{C}$ suggests a slight reduction of the stronger acid sites when rising the calcination temperature from 600 to $900{ }^{\circ} \mathrm{C}$. In addition, the total number of acidic sites was clearly reduced, when rising the calcination temperature. Base strength distribution showed the same trend as the acid strength distribution, when comparing both $\mathrm{YZrO}$ catalysts. Acidic and basic sites on which $\mathrm{NH}_{3}$ and $\mathrm{CO}_{2}$ adsorbed at temperatures higher than $325^{\circ} \mathrm{C}$ are considered to be poisoned in the reaction at $325^{\circ} \mathrm{C}$. As long as strong acidic and strong basic sites measured by the desorption at $>325^{\circ} \mathrm{C}$, the amounts of acidic and basic sites of $\mathrm{YZrO}$ calcined at $600^{\circ} \mathrm{C}$ were calculated to be 0.041 and $0.074 \mathrm{mmol} \mathrm{g}^{-1}$, while those of $\mathrm{YZrO}$ calcined at $900^{\circ} \mathrm{C}$ were 0.015 and $0.022 \mathrm{mmol} \mathrm{g}^{-1}$, respectively. 


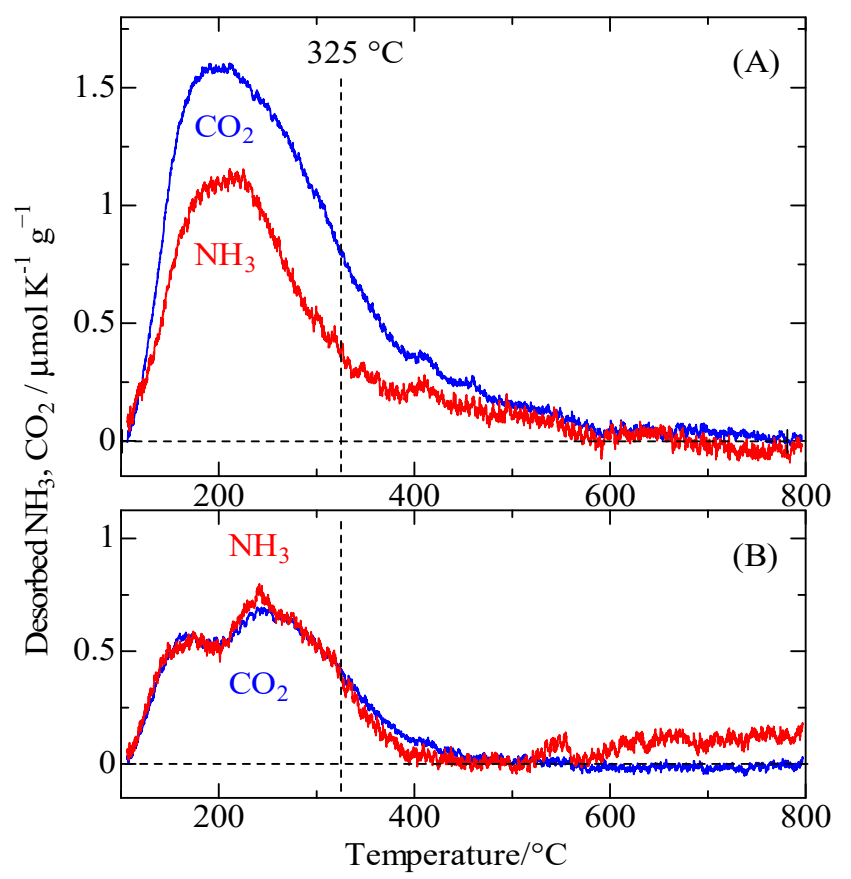

Figure 9. TPD profiles of adsorbed $\mathrm{NH}_{3}$ and $\mathrm{CO}_{2}$ on $\mathrm{YZrO}$ calcined at $600(\mathrm{~A})$ and $900{ }^{\circ} \mathrm{C}(\mathbf{B})$.

\section{Discussion}

\subsection{Structure of REZrO as an Effective Catalyst for the Dehydration of BDOs}

In the preparation of zirconate, $\mathrm{KOH}$ is frequently used as a mineralizer: $\mathrm{La}_{2} \mathrm{Zr}_{2} \mathrm{O}_{7}$ is synthesized through the $\mathrm{HT}$ process of double hydrous oxides of $\mathrm{La}$ and $\mathrm{Zr}$ using $\mathrm{KOH}$ as the mineralizer [42]. Liu et al. have synthesized REZrO ceramics such as $\mathrm{Yb}_{2} \mathrm{Zr}_{2} \mathrm{O}_{7}$ and $\mathrm{Gd}_{2} \mathrm{Zr}_{2} \mathrm{O}_{7}$ at calcination temperatures above $1550{ }^{\circ} \mathrm{C}$ [43]. An example of REZrO for catalyst use is rare; Fang et al. recently reported that oxygen-defected fluorite $\mathrm{Y}_{2} \mathrm{Zr}_{2} \mathrm{O}_{7}$ is prepared with a simple co-precipitation method using ammonia as a precipitant: the sample calcined at $800{ }^{\circ} \mathrm{C}$ has $S A$ as small as $7 \mathrm{~m}^{2} \mathrm{~g}^{-1}$ and is used for methane oxidative coupling [36]. We previously prepared REZrO samples in $\mathrm{HT}$ conditions using $\mathrm{KOH}$ solution, but they had small $S A$ values at most $10 \mathrm{~m}^{2} \mathrm{~g}^{-1}$ and showed low conversion in the dehydration of 1,3-BDO [35]. However, $\mathrm{Yb}_{2} \mathrm{Zr}_{2} \mathrm{O}_{7}$ prepared by HT aging using ammonia has a high $S A$ of $49 \mathrm{~m}^{2} \mathrm{~g}^{-1}$ and shows an excellent catalytic activity in the dehydration of 1,3-BDO. Thus, HT aging with ammonia mineralizer would be promising for the preparation of catalyst samples with high crystallinity and high $S A$. In this paper, we obtained REZrO samples with high $S A$ between 16 and $39 \mathrm{~m}^{2} \mathrm{~g}^{-1}$ (Table 1) in HT treatment using ammonia as a mineralizer.

In our previous paper [35], $\mathrm{La}_{2} \mathrm{O}_{3}-\mathrm{ZrO}_{2}, \mathrm{Nd}_{2} \mathrm{O}_{3}-\mathrm{ZrO}_{2}$, and $\mathrm{Sm}_{2} \mathrm{O}_{3}-\mathrm{ZrO}_{2}$ prepared in the HT process using $\mathrm{KOH}$ as a mineralizer were determined to be pyrochlore-type $\mathrm{Ln}_{2} \mathrm{Zr}_{2} \mathrm{O}_{7}$. The reason is that the ionic radius ratio of $\mathrm{Ln} / \mathrm{Zr}$ determines the structure of $\mathrm{Ln}_{2} \mathrm{Zr}_{2} \mathrm{O}_{7}$ [44]: it is reported that the pyrochlore-type structure is favored at the ionic radius ratio of $\mathrm{Ln} / \mathrm{Zr}$ between 1.46 and 1.78, while the defect fluorite-type structure is favorable at a ratio less than 1.46. At the ratio of $1.46, \mathrm{Gd}_{2} \mathrm{Zr}_{2} \mathrm{O}_{7}$ could have both structures. In the continuous scanning XRD patterns (Figure 2), structures of the samples are assigned by comparing the PDF database. Most of the structural data of REZrOs of heavy rare earth were fitted with the database of cubic fluorite-type $\mathrm{RE}_{2} \mathrm{Zr}_{2} \mathrm{O}_{7}$, as described in Section 2.1. In the case of $\mathrm{YZrO}$, however, the structure was fitted with both pyrochlore and fluorite phases. In Figure 5, Rietveld analysis of the $\mathrm{YZrO}$ calcined at $1200{ }^{\circ} \mathrm{C}$ clearly indicates the structure is fluorite. It is confirmed that the active $\mathrm{YZrO}$ is composed of defect fluorite-type $\mathrm{Y}_{2} \mathrm{Zr}_{2} \mathrm{O}_{7}$, but not pyrochlore. The structure is the same as that of oxygen-defected fluorite $\mathrm{Yb}_{2} \mathrm{Zr}_{2} \mathrm{O}_{7}$, which is reported previously [35]. 


\subsection{Dehydration of Different BDOs over Various REZrO Catalysts}

In the catalyst screening, it is concluded that the reactivity order of BDOs over each REZrO catalyst is $1,3-\mathrm{BDO}>1,4-\mathrm{BDO}>2,3-\mathrm{BDO}$. In this work, $\mathrm{YZrO}$ is the most active catalyst as a weight basis for the vapor-phase dehydration of 1,4- and 1,3-BDO. We have previously reported efficient rare earth oxide catalysts for the dehydration of 1,4-BDO to produce 3B1ol [17]: rare earth oxides such as $\mathrm{Er}_{2} \mathrm{O}_{3}$, $\mathrm{Yb}_{2} \mathrm{O}_{3}$, and $\mathrm{Lu}_{2} \mathrm{O}_{3}$ show the highest $3 \mathrm{~B} 1 \mathrm{ol}$ formation rates in the catalytic reaction. The formation rate varies with the ionic radius of the rare earth cation.

Here, we summarized the relationship between the formation rate and the ionic radius of the rare earth cation. Figure 10 shows the intrinsic activity of REZrO catalyst: the formation rate of UOLs per unit surface area with the variation of ionic radius of rare earth cation (Figure 10A) and average ionic radius between $\mathrm{Zr}^{4+}$ and rare earth cation, $R_{(\mathrm{RE}+\mathrm{Zr}) / 2}$ (Figure 10B). The formation rate of UOLs per unit surface area was calculated from the data in Table 2, Table 3, and Table S3 for the dehydration of 1,4-, 2,3-, and 1,3-BDO, respectively. In the present study, REZrO catalysts with heavy rare earth cations such as DyZrO, HoZrO, YZrO, ErZrO, YbZrO, and LuZrO show the comparable formation rate of UOLs, YbZrO shows the highest UOLs formation rates among the REZrOs in the dehydration of both 1,3- and 1,4-BDO (Figure 10A). In comparison with pure rare earth oxides, we adapted a mathematical mean of ionic radius between $\mathrm{RE}$ and $\mathrm{Zr}$, which is listed in Table 1 . The mathematical mean of ionic radius between $\mathrm{Gd}$ and $\mathrm{Zr}, R_{(\mathrm{Gd}+\mathrm{Zr}) / 2}$, is calculated to be $0.0889 \mathrm{~nm}$ and that between $\mathrm{Dy}$ and $\mathrm{Zr}$, $R_{(\mathrm{Dy}+\mathrm{Zr}) / 2}=0.0876 \mathrm{~nm}$, where $R_{\mathrm{Gd}}=0.0938, R_{\mathrm{Dy}}=0.0912$, and $R_{\mathrm{Zr}}=0.0840 \mathrm{~nm}$ [37]. In Figure 10B, the formation rates over REZrO are larger than those over pure rare earth oxides reported in Ref. [45]. Pure $\mathrm{CeO}_{2}$ has exceptionally high activity in the dehydration of 1,3-BDO; it shows the highest formation rate of $3.85 \mathrm{mmol} \mathrm{h}^{-1} \mathrm{~m}^{-2}$ at the ionic radius of $\mathrm{Ce}^{4+}, 0.0970 \mathrm{~nm}$, as shown in Figure 10B with the dotted line. Active $\mathrm{REZrO}$ catalysts appear in a narrow range of ionic radius. The mean ionic radii of $0.0889 \mathrm{~nm}$ for $\mathrm{GdZrO}$ and $0.0854 \mathrm{~nm}$ for $\mathrm{YbZrO}$ are close to the ionic radii of $\mathrm{Er}^{3+}$ in $\mathrm{Er}_{2} \mathrm{O}_{3}$ and $\mathrm{Lu}^{3+}$ in $\mathrm{Lu}_{2} \mathrm{O}_{3}$, which are 0.0890 and $0.0861 \mathrm{~nm}$, respectively [45]. The mean ionic radius of $0.0870 \mathrm{~nm}$, $R_{(\mathrm{Y}+\mathrm{Zr}) / 2}$, for $\mathrm{YZrO}$ is close to the ionic radius of $\mathrm{Yb}^{3+}$ of 0.0868 in $\mathrm{Yb}_{2} \mathrm{O}_{3}$, which is reported to be an active catalyst for the dehydration of 1,4-BDO [46]. This suggests that crystallites with specific size of unit cell are efficient for the selective formation of 3B1ol. Besides, because yttrium is abundant and cheap among rare earth elements, we investigated the $\mathrm{YZrO}$ catalyst in detail.
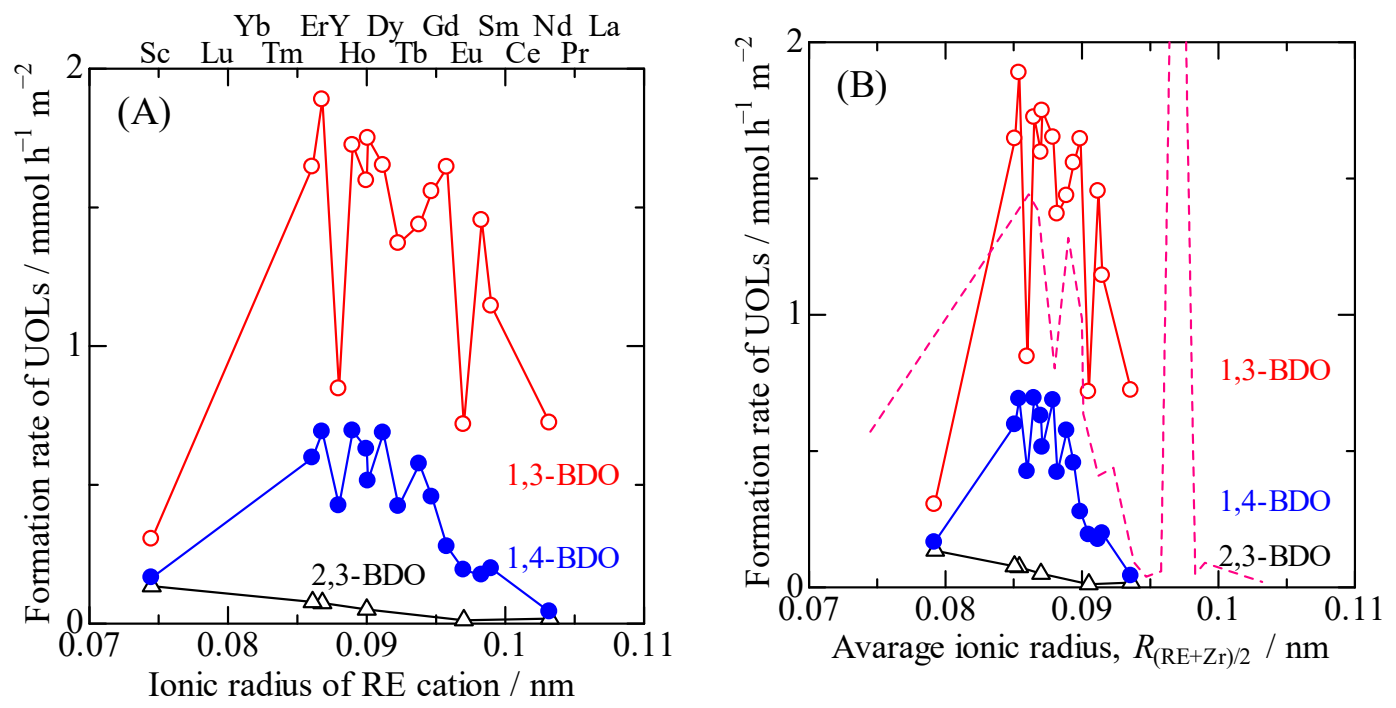

Figure 10. Changes in the formation rate of unsaturated alcohols (UOLs) in the dehydration of BDOs over REZrO catalysts at $325^{\circ} \mathrm{C}$ with ionic radius of rare earth cation (A) and average ionic radius between $\mathrm{Zr}^{4+}$ and rare earth cation, $R_{(\mathrm{RE}+\mathrm{Zr}) / 2}(\mathrm{~B})$. A dotted line in Figure 10B indicates the formation rate in the dehydration of 1,3 -BDO over pure rare earth oxide with ionic radius of rare earth cation, reported in Ref. [45]. 


\subsection{Significant Parameters on the Catalytic Activity of $\mathrm{YZrO}$}

As shown in Figure 6, the calcination temperature of $\mathrm{YZrO}$ significantly affects the conversion of 1,4-BDO. The effect of calcination temperature on the 1,4-BDO conversion over $\mathrm{YZrO}$ is quite similar to those observed in the reaction over pure rare earth oxides such as $\mathrm{Er}_{2} \mathrm{O}_{3}, \mathrm{Lu}_{2} \mathrm{O}_{3}$ [46], and $\mathrm{CeO}_{2}$ [47]. The significant increase in the activity is probably attributed to the change in the ratio of exposed crystal surface with the particle sizes.

In Table $7, \mathrm{H}_{2}$ carrier gas accelerates the formation of $3 \mathrm{~B} 1 \mathrm{ol}$ at $325^{\circ} \mathrm{C}$. It has been reported in the literature that the acceleration by $\mathrm{H}_{2}$ in the dehydration of BDOs: 1,4-BDO over $\mathrm{CaO} / \mathrm{ZrO}_{2}$ [33] and 2,3-BDO over $\mathrm{Sc}_{2} \mathrm{O}_{3}$ [39]. In the dehydration of 1,3-BDO over $\mathrm{Er}_{2} \mathrm{O}_{3}$, however, the formation of UOLs is depressed in $\mathrm{H}_{2}$ flow [45]. The effect of $\mathrm{H}_{2}$ carrier gas depends on the types of reactants and catalysts. Anyway, $\mathrm{H}_{2}$ gas accelerates the formation of 3B1ol in the dehydration of 1,4-BDO over $\mathrm{YZrO}$ catalyst, $\mathrm{Y}_{2} \mathrm{Zr}_{2} \mathrm{O}_{7}$. Fluorite $\mathrm{Y}_{2} \mathrm{Zr}_{2} \mathrm{O}_{7}$ has essentially oxygen defect sites on the catalyst surface, as discussed in the following section. It is well known that $\mathrm{ZrO}_{2}$ as well as fluorite $\mathrm{CeO}_{2}$ has oxygen storage capacity [48]. In addition to the original oxygen defects, oxygen vacancies could be generated on the surface of $\mathrm{YZrO}$ due to the oxidation of $\mathrm{H}_{2}$. The generation of oxygen vacancies by the oxidation of $\mathrm{H}_{2}$ might be the reason for enhancing the catalytic performance of $\mathrm{YZrO}$ in $\mathrm{H}_{2}$ flow.

In Table S2, the variation of the UOLs formation rate with $W / F$ was almost constant at conversions lower than $80 \%$ : the formation rate was $0.69 \mathrm{mmol} \mathrm{m}^{-2} \mathrm{~h}^{-1}$ at a conversion of $77.6 \%$ while that at $51.5 \%$ conversion was $0.75 \mathrm{mmol} \mathrm{m}^{-2} \mathrm{~h}^{-1}$. Then, we estimated the effect of external mass transfer using Carberry number ( $\mathrm{Ca}$ ) [49]. Ca was calculated to be 0.05 at a conversion of $73 \%$. Because an external concentration gradient is absent at $\mathrm{Ca}<0.05$, the effect of external mass transfer would be small at a conversion of lower than $73 \%$. In contrast, at high conversions over $73 \%$, a catalyst efficiency becomes low due to mass transfer limitation in this study. Thus, in Figure 10, some of the formation rate of UOLs calculated from the conversion data over $73 \%$ could be underestimated. At high conversions near $100 \%$ without $1,4-\mathrm{BDO}$, subsequent reactions proceeded: the dehydration of 3B1ol to BD and the isomerization of 3B1ol proceed (Figure 7).

Besides, we exhibited that $\mathrm{BD}$ was produced as a by-product in the dehydration of 1,4-BDO over $\mathrm{YZrO}$ even at $300{ }^{\circ} \mathrm{C}$ (Table 6). We have previously reported that 1,4-BDO can be selectively converted to $\mathrm{BD}$ via an intermediate of $3 \mathrm{~B} 1 \mathrm{ol}$ over $\mathrm{Yb}_{2} \mathrm{O}_{3}$ at $360^{\circ} \mathrm{C}$ [40]. To establish an efficient catalytic system for the production of $\mathrm{BD}$ from 1,4-BDO, we need selective dehydration catalysts for 3B1ol without decomposition to propylene. We could obtain several candidates for the stepwise dehydration of 1,4-BDO (Table 2). Thus, the BD formation in the dehydration of 1,4-BDO will be reported in the following paper in a near future.

The dehydration of alcohols readily proceeds over strong acidic catalysts, but it is not easy that single dehydration of glycols proceeds to produce selectively UOLs [50,51]: the reason is that step-wise reactions of the produced UOLs frequently proceed over acidic catalysts. Catalysts with acid-base properties are reported to be effective for the formation of 3B1ol in the dehydration of 1,4-BDO [33,46]. $\mathrm{NH}_{3}$ and $\mathrm{CO}_{2}$ gases work as weak poisons for $\mathrm{CaO} / \mathrm{ZrO}_{2}$ and $\mathrm{Er}_{2} \mathrm{O}_{3}$ catalysts to reduce the yield of 3B1ol whereas the dehydration proceeds even in the $\mathrm{NH}_{3}$ atmosphere. In the dehydration of 2,3-BDO, both $\mathrm{NH}_{3}$ and $\mathrm{CO}_{2}$ also work as the poisons for the formation of $3 \mathrm{~B} 2$ ol over $\mathrm{CaO} / \mathrm{ZrO}_{2}$ [52]. In Table 7 , $\mathrm{CO}_{2}$ gas works as a poison of basic sites, but gaseous $\mathrm{NH}_{3}$ accelerates the dehydration. Although the reason for the acceleration by $\mathrm{NH}_{3}$ is not clear, an $\mathrm{NH}_{3}$ gas may act as a base catalyst together with catalyst surface for the abstraction of hydrogen from 1,4-BDO. In a similar manner, over pure $\mathrm{ZrO}_{2}$ with acidic property, it is observed that the formation of 3B1ol form 1,4-BDO is accelerated under $\mathrm{NH}_{3}$ flow conditions [33]. As shown in Figure S3, either hydrogen-bonded or weakly adsorbed molecular $\mathrm{NH}_{3}$ acts as a base catalyst. After it removes from the surface during the reaction, $\mathrm{NH}_{3}$ adsorbed on $\mathrm{YZrO}$ acted as a poison of acidic sites. In the formation of THF, however, the formation of THF is affected by the acidic sites because the selectivity is depressed by $\mathrm{NH}_{3}$. A similar trend in the THF formation is reported in the dehydration of 1,4-BDO [33,46]. 


\subsection{Mechanistic Considerations on the Dehydration of 1,4-BDO over YZrO Catalyst}

Although $\mathrm{YZrO}$ samples have both acidic and basic sites, the TPD results (Figure 9) cannot explain the results that $Y Z r O$ samples calcined at high temperatures have high catalytic performance. Thus, it is reasonable that the change in the ratio of exposed crystal surface with large particle sizes could be the main reason for the catalytic performance enhanced in the $\mathrm{YZrO}$ calcined at $900{ }^{\circ} \mathrm{C}$.

As shown in Section 3.2 (Table 5), $\mathrm{YZrO}$ samples are composed of $\mathrm{Y}_{2} \mathrm{Zr}_{2} \mathrm{O}_{7}$ with an oxygen-defected fluorite structure, which is the same structure of previously reported $\mathrm{Yb}_{2} \mathrm{Zr}_{2} \mathrm{O}_{7}$ [35]. We have discussed structures of active sites for the dehydration of 1,3-BDO using a crystal model of $\mathrm{Yb}_{2} \mathrm{Zr}_{2} \mathrm{O}_{7}$ and proposed probable model structures of active sites. As shown in the previous report [35], well-crystalized $\mathrm{Yb}_{2} \mathrm{Zr}_{2} \mathrm{O}_{7}$ inevitably has oxygen defect sites on the surface. The defect site exposes three cations such as $\mathrm{Zr}^{4+}$ and $\mathrm{Yb}^{3+}$, which act as an acidic site, and it is surrounded by six $\mathrm{O}^{2-}$ anions, which act as a basic site. Because the crystal structure of $\mathrm{Y}_{2} \mathrm{Zr}_{2} \mathrm{O}_{7}$ is the same as that of $\mathrm{Yb}_{2} \mathrm{Zr}_{2} \mathrm{O}_{7}$, cations such as $\mathrm{Zr}^{4+}$ and $\mathrm{Y}^{3+}$ exposed on the $\mathrm{O}^{2-}$ defect site could work as acidic sites, and an $\mathrm{O}^{2-}$ anion surrounding the defect site would work as a basic site (adsorption site in Figure 11A). It is reasonable that the selective dehydration of BDOs to UOLs would proceed via an acid-base concerted mechanism over the basic site of $\mathrm{O}^{2-}$ and the acidic sites of $\mathrm{Zr}^{4+}$ and $\mathrm{Y}^{3+}$.

(A)

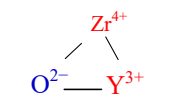

Adsorption site

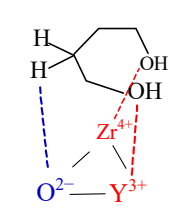

$1,4-\mathrm{BDO}$

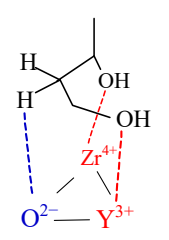

1,3-BDO

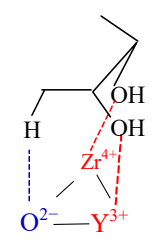

2,3-BDO

(B)

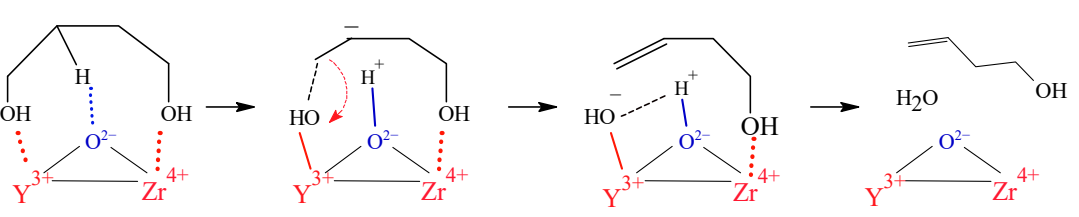

(C)

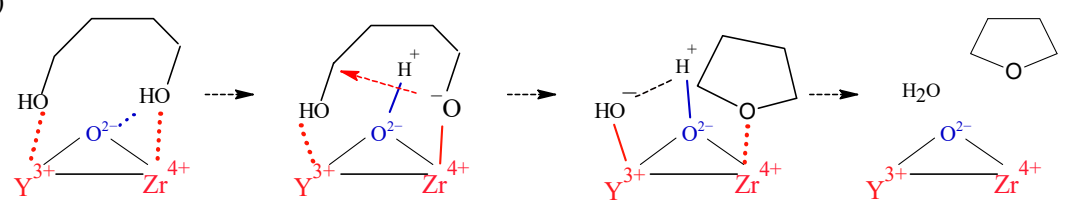

Figure 11. Possible coordination structures with adsorption site $(\mathbf{A})$ and reaction mechanism for the dehydration of 1,4-BDO to form 3B1ol (B) and THF (C).

In the dehydration of BDOs, UOLs formation could be initiated by tridentate coordination with two $\mathrm{OH}$ groups of $\mathrm{BDO}$ on the acidic cation sites and a hydrogen of $\mathrm{BDO}$ on the basic $\mathrm{O}^{2-}$ site. We speculate possible tridentate coordination structures of $\mathrm{BDO}$ adsorbed on $\mathrm{YZrO}$ surface (Figure 11A). In Figure 11A, an acceptable adsorption structure of 1,4-BDO has a 6-membered ring, $\mathrm{Y}^{3+}-\mathrm{O}-\mathrm{C}-\mathrm{C}-\mathrm{H}-\mathrm{O}^{2-}$, a 7-membered ring, $\mathrm{O}^{2-}-\mathrm{H}-\mathrm{C}-\mathrm{C}-\mathrm{C}-\mathrm{O}-\mathrm{Zr}^{4+}$, and an 8-membered ring, $\mathrm{Y}^{3+}-\mathrm{O}-\mathrm{C}_{4}-\mathrm{O}-\mathrm{Zr}^{4+}$. In the dehydration of 1,3- and 2,3-BDO, adsorption structures have 7- and 6-membered ring, $\mathrm{Y}^{3+}-\mathrm{O}-\mathrm{C}_{n}-\mathrm{O}-\mathrm{Zr}^{4+}$ ( $n=3$ and 2), respectively. It is reasonable that the accessibility of hydrogen after the coordination of $\mathrm{HO}$ groups, $\mathrm{Y}^{3+}-\mathrm{O}-\mathrm{C}_{n}-\mathrm{O}-\mathrm{Zr}^{4+}(n=3$ and 2$)$, determines the reactivity because the anchoring $\mathrm{OH}$ group is important for the formation of UOLs [15,34]. The low reactivity of 2,3-BDO is probably caused by large strain in the tridentate coordination structure, which has two 6-membered rings such as $\mathrm{Y}^{3+}-\mathrm{O}-\mathrm{C}_{2}-\mathrm{O}-\mathrm{Zr}^{4+}$ and $\mathrm{O}^{2-}-\mathrm{H}-\mathrm{C}-\mathrm{C}-\mathrm{O}-\mathrm{Y}^{3+}$, and a 7-membered ring of $\mathrm{O}^{2-}-\mathrm{H}-\mathrm{C}-\mathrm{C}-\mathrm{C}-\mathrm{O}-\mathrm{Zr}^{4}$, as shown in Figure 11A. The 6-membered ring for the fixation of $\mathrm{OH}$ groups as $\mathrm{Y}^{3+}-\mathrm{O}-\mathrm{C}-\mathrm{C}-\mathrm{O}-\mathrm{Zr}^{4+}$ will induce large strain in the tridentate coordination. On the other hand, in the dehydration of 1,3- and 1,4-BDO, 7- and 8-membered ring coordination, $\mathrm{Y}^{3+}-\mathrm{O}-\mathrm{C}_{n}-\mathrm{O}-\mathrm{Zr}^{4+}(n=3$ and 4$)$, respectively, which is looser 
than 6-membered ring of $\mathrm{Y}^{3+}-\mathrm{O}-\mathrm{C}_{2}-\mathrm{O}-\mathrm{Zr}^{4+}$ in 2,3-BDO, can allow a hydrogen of BDO to access a basic $\mathrm{O}^{2-}$ site to form tridentate coordination structure. It is speculated that the 7-membered ring, $\mathrm{Y}^{3+}-\mathrm{O}-\mathrm{C}_{3}-\mathrm{O}-\mathrm{Zr}^{4+}$, in 1,3-BDO is more stable than the 8-membered ring, $\mathrm{Y}^{3+}-\mathrm{O}-\mathrm{C}_{4}-\mathrm{O}-\mathrm{Zr}^{4+}$, in 1,4-BDO. It is probable that this could be the reason for the difference in the reactivity of BDOs.

Figure 11B proposes a speculative reaction mechanism for the dehydration of 1,4-BDO to produce $3 \mathrm{~B} 1 \mathrm{ol}$. The selective dehydration of 1,4-BDO to produce 3B1ol over the defect site is explained by the adsorption as the form of tridentate coordination of 1,4-BDO to the 2 cations and an $\mathrm{O}^{2-}$ anion followed by sequential dehydration: the position- 2 hydrogen of 1,4-BDO is firstly abstracted by a basic $\mathrm{O}^{2-}$ anion and then the position-1 hydroxyl group is subsequently or simultaneously abstracted by an acidic $\mathrm{Y}^{3+}$ cation. Probably, the first and the second steps in Figure 11B would proceed simultaneously. Another $\mathrm{OH}$ group at position 4 plays an important role in anchoring 1,4-BDO to the catalyst surface. Thus, the selective dehydration of 1,4-BDO to 3B1ol could proceed via the speculative base-acid concerted mechanism, in a similar manner to the 1,4-BDO dehydration catalyzed by $\operatorname{Er}_{2} \mathrm{O}_{3}$ catalyst, which is supported by theoretical calculation [30].

In the formation of THF, a speculative model could be proposed (Figure 11C). The strength of the acidic site is not strong so that carbocation generated by the abstraction of the $\mathrm{OH}$ group could not be formed. The TPD results in Figure 9 could explain the result that the $\mathrm{YZrO}$ calcined at $600^{\circ} \mathrm{C}$, which has acidic sites stronger than that calcined at $900{ }^{\circ} \mathrm{C}$, shows the higher selectivity to THF than that calcined at $900{ }^{\circ} \mathrm{C}$ (Figure 6). Thus, base-acid concerted mechanism can be considered. However, the adsorption structure in Figure $11 \mathrm{C}$ is highly strained because it has an 8-membered ring, $\mathrm{Y}^{3+}-\mathrm{O}-\mathrm{C}_{4}-\mathrm{O}-\mathrm{Zr}^{4+}$, and a 9-membered ring, $\mathrm{Y}^{3+}-\mathrm{O}-\mathrm{C}_{4}-\mathrm{O}-\mathrm{H}-\mathrm{O}^{2-}$. The suppression of the major by-product, $\mathrm{THF}$, is significant to improve the selectivity to $3 \mathrm{~B} 1 \mathrm{ol}$.

\section{Materials and Methods}

\subsection{Materials}

$\mathrm{ZrO}\left(\mathrm{NO}_{3}\right)_{2} \cdot 2 \mathrm{H}_{2} \mathrm{O}, \mathrm{La}\left(\mathrm{NO}_{3}\right)_{3} \cdot 6 \mathrm{H}_{2} \mathrm{O}, \operatorname{Pr}\left(\mathrm{NO}_{3}\right)_{3} \cdot \mathrm{nH}_{2} \mathrm{O}$, and $\mathrm{Sm}\left(\mathrm{NO}_{3}\right)_{3} \cdot 6 \mathrm{H}_{2} \mathrm{O}$ were purchased from Wako Pure Chemicals Industries, Ltd., Osaka, Japan, and $\mathrm{Ce}\left(\mathrm{NO}_{3}\right)_{3} \cdot 6 \mathrm{H}_{2} \mathrm{O}$ was purchased from Nakalai Tesque, Inc., Kyoto, Japan. Other rare earth (RE) nitrates such as $\mathrm{Y}\left(\mathrm{NO}_{3}\right)_{3} \cdot 6 \mathrm{H}_{2} \mathrm{O}$ were purchased from Sigma-Aldrich, St. Louis, Missouri, US. In the preparation of $\mathrm{Y}_{2} \mathrm{O}_{3}-\mathrm{ZrO}_{2}$ with a $\mathrm{Y} / \mathrm{Zr}$ ratio of 1, for example, $3.24 \mathrm{~g}$ of $\mathrm{Y}\left(\mathrm{NO}_{3}\right)_{3} \cdot 6 \mathrm{H}_{2} \mathrm{O}$ and $2.26 \mathrm{~g}$ of $\mathrm{ZrO}\left(\mathrm{NO}_{3}\right)_{2} \cdot 2 \mathrm{H}_{2} \mathrm{O}$ were dissolved in $50 \mathrm{~cm}^{3}$ of distilled water. Then, the $\mathrm{pH}$ value of the solution was adjusted to 10 with $25 \mathrm{wt} . \%$ ammonia water under stirring. After the solution was transferred into $100 \mathrm{~cm}^{3}$ Teflon-lined autoclave, HT treatment was typically performed at $200{ }^{\circ} \mathrm{C}$ for $24 \mathrm{~h}$. The recovered precipitate was centrifuged, washed with distilled water, dried at $110^{\circ} \mathrm{C}$ for $18 \mathrm{~h}$, and finally calcined at $900{ }^{\circ} \mathrm{C}$ for $3 \mathrm{~h}$. Hereafter, the resulted $\mathrm{Y}_{2} \mathrm{O}_{3}-\mathrm{ZrO}_{2}$ is named as $\mathrm{YZrO}$. In the case of $\mathrm{REZrO}$, a sample was prepared in the same way as $\mathrm{YZrO}$ except using a rare earth nitrate instead of using $\mathrm{Y}\left(\mathrm{NO}_{3}\right)_{3} \cdot 6 \mathrm{H}_{2} \mathrm{O}$. The resulting zirconate with $50 \mathrm{~mol} \%$ $\mathrm{RE}$ is named as REZrO. For example, the $50 \mathrm{~mol} \%$ Dy-containing $\mathrm{ZrO}_{2}$ is named as DyZrO.

Reactant chemicals such as 1,4- and 1,3-BDO were purchased from Wako Pure Chemicals Industries, Ltd., Osaka, Japan. 2,3-BDO was purchased from Tokyo Chemical Industry, Co., Ltd. Tokyo, Japan. They were used for the catalytic reaction without any further purification.

\subsection{Characterization of Catalysts}

X-ray fluorescence (XRF) analysis for the estimation of RE content in REZrO samples was performed by EDX-900HS (Shimadzu, Kyoto, Japan). The continuous scanning X-ray diffraction (XRD) was recorded on New D8 ADVANCE (Bruker Japan, Yokohama, Japan) with $\mathrm{Cu} K \alpha$ radiation $(\lambda=$ $0.154 \mathrm{~nm}$ ) to identify the crystal phase of the catalyst. A crystallite size, $D_{\mathrm{XRD}}$, of $Y Z \mathrm{ZO}$ sample was calculated from the full width at half maximum (FWHM) by Scherrer equation: $D_{\mathrm{XRD}}=K \lambda /(\beta \cos \theta)$, where $K(=0.9), \lambda, \beta$, and $\theta$ are the shape factor, X-ray wavelength, FWHM, and Bragg's diffraction angle, respectively. The step-scanning XRD of $\mathrm{YZrO}$ calcined at $1200^{\circ} \mathrm{C}$ was recorded on XRD-7000 
(Shimadzu, Kyoto, Japan) with $\mathrm{Cu} \mathrm{K} \alpha$ radiation in order to refine structure parameter by Rietveld analysis, which was operated by using RIETAN-FP program [53]. High-resolution field emission scanning electron microscope (FE-SEM) image was observed on JSM-7100FA microscope (JEOL, Tokyo, Japan) operated at $15 \mathrm{kV}$.

The $\mathrm{N}_{2}$ adsorption isotherm of catalyst was measured in a self-made gas adsorption apparatus at $-196{ }^{\circ} \mathrm{C}$, and the $S A$ of catalyst was calculated from the $\mathrm{N}_{2}$ isotherm fitted with the Brunauer-Emmett-Teller (BET) equation. A particle size of $\mathrm{Y}_{2} \mathrm{Zr}_{2} \mathrm{O}_{7}, D_{\mathrm{BET}}$, was calculated by the following equation, $D_{\mathrm{BET}}=6 / \mathrm{d} S A$, assuming that the primary particles are spherical or cubic where $d$ is the density of $\mathrm{Y}_{2} \mathrm{Zr}_{2} \mathrm{O}_{7}\left(d=5.36 \mathrm{~g} \mathrm{~cm}^{-3}\right.$, which is an arithmetic average of 5.03 and $5.68 \mathrm{~g} \mathrm{~cm}^{-3}$ for $\mathrm{Y}_{2} \mathrm{O}_{3}$ and $\mathrm{ZrO}_{2}$, respectively [54]). The calculation of $D_{\mathrm{BET}}$ was also performed to compare the morphology of catalyst [55-57].

TPD of adsorbed $\mathrm{NH}_{3}$ and $\mathrm{CO}_{2}$ was performed using BELCATII (Microtrac BEL Corp., Osaka, Japan) with thermal conductivity detector (TCD) to estimate the acidity and the basicity of catalysts, respectively. The measurement conditions are the following: preheating the sample in He flow at $500^{\circ} \mathrm{C}$ for $1 \mathrm{~h}$; adsorption of $\mathrm{NH}_{3}$ or $\mathrm{CO}_{2}$ at $100^{\circ} \mathrm{C}$ for $1 \mathrm{~h}$; desorption temperature controlled from 100 to $800{ }^{\circ} \mathrm{C}$ at an increment rate of $10^{\circ} \mathrm{C} \mathrm{min}^{-1}$. The TCD detector can detect gases such as water and oxygen desorbed from the catalyst. Thus, we also performed a blank TPD experiment for the sample preheated at $500{ }^{\circ} \mathrm{C}$ without adsorption of $\mathrm{NH}_{3}$. Figure $\mathrm{S} 4$ shows the blank TCD signal profile as a function of temperature together with the original TCD signals of adsorbed $\mathrm{NH}_{3}$ and $\mathrm{CO}_{2}$. A difference TCD signal between $\mathrm{NH}_{3}$ adsorption and the blank TPD profile was converted to a $\mathrm{NH}_{3}$-TPD profile using molar sensitivity of $\mathrm{NH}_{3}$. In a similar manner, the $\mathrm{CO}_{2}$-TPD profile was obtained from the difference TCD signal between $\mathrm{CO}_{2}$ adsorption and the blank TPD profile. The amounts of acidic and basic sites were estimated from the integral of the desorption profiles of $\mathrm{NH}_{3}$ and $\mathrm{CO}_{2}$, respectively.

\subsection{Catalytic Reaction}

The vapor-phase dehydration of a $\mathrm{BDO}$ was performed in a fixed-bed down-flow glass tube reactor under an atmospheric pressure of $\mathrm{N}_{2}$ at a temperature between 300 and $375{ }^{\circ} \mathrm{C}$, typically at $325^{\circ} \mathrm{C}$. After $0.50 \mathrm{~g}$ of a catalyst with the granule size of $53-250 \mu \mathrm{m}$ had been heated in $\mathrm{N}_{2}$ flow at the prescribed reaction temperature for $1 \mathrm{~h}$, a reactant $\mathrm{BDO}$ was fed into the reactor at a liquid feed rate of $1.60 \mathrm{~g} \mathrm{~h}^{-1}$ together with an $\mathrm{N}_{2}$ carrier gas at $30 \mathrm{~cm}^{3} \mathrm{~min}^{-1}$. The reaction effluent at $325^{\circ} \mathrm{C}$ was collected at $-78{ }^{\circ} \mathrm{C}$ every hour, whereas it was collected at $0^{\circ} \mathrm{C}$ in the case of the conversion over $80 \%$ and the reaction temperature over $325^{\circ} \mathrm{C}$. Differences in the temperature of cold trap were described in the SI file (Table S4). The collected liquid products were identified using a gas chromatograph (GC) equipped with mass-spectrometer (QP5050A, Shimadzu, Kyoto, Japan) and a capillary column (DB-WAX, a length of $30 \mathrm{~m}$, JW Scientific, Osaka, Japan), and they were analyzed by a GC (GC-8A, Shimadzu, Kyoto, Japan) equipped with flame ionization detector and a capillary column of Inert Cap WAX-HT (an inner diameter of $0.53 \mathrm{~mm}$ and a length of $30 \mathrm{~m}$, GL-Science, Tokyo, Japan). 1-Hexanol was used as an internal standard for the quantitative GC analysis. The gaseous products, such as BD, propylene, and $\mathrm{CO}_{2}$, collected using a gastight syringe with a volume of $0.5 \mathrm{~cm}^{3}$ were analyzed by another GC-8A equipped with TCD and a packed column (VZ-7, a length of $6 \mathrm{~m}$, GL-Science, Tokyo, Japan) using the $\mathrm{N}_{2}$ carrier gas as an internal standard.

The catalytic reaction was performed during the initial TOS of $5 \mathrm{~h}$ to assure the stability of the catalytic activity. All the catalysts showed a little decay in the initial period of $1 \mathrm{~h}$ so that we evaluated the catalytic activity we evaluated by averaging the data of conversion and selectivity for $4 \mathrm{~h}$ from TOS of 1 to $5 \mathrm{~h}$ excluding the first period of $1 \mathrm{~h}$. The mass recovered in the effluent liquid was more than $97 \%$ of the mass feed. The error of reproducibility was within 3\%. The conversion and selectivity were calculated according to the following equations:

$$
\text { Conversion }(\%)=\left(1-\frac{\text { mole of the recovered reactant }}{\text { mole of the fed reactant }}\right) \times 100
$$




$$
\text { Selectivity }(\mathrm{mol} \%)=\frac{\text { mole of carbone in the specific product }}{\text { mole of carbon in the fed reactant } \times \text { Conversion } / 100} \times 100
$$

The poisoning experiment of $\mathrm{YZrO}$ catalyst was performed in the catalytic dehydration of 1,4-BDO at 300 and $325^{\circ} \mathrm{C}$ to confirm whether acidic and basic carrier gases affect the catalytic activity or not. Instead of using $\mathrm{N}_{2}$ gas, $\mathrm{CO}_{2}, \mathrm{NH}_{3}$, or $\mathrm{H}_{2}$ was used as a carrier gas at a flow rate of $30 \mathrm{~cm}^{3} \mathrm{~min}^{-1}$ in the catalytic reaction. The reaction effluent was collected at $0^{\circ} \mathrm{C}$ in the poisoning experiment. In another poisoning experiment, the catalytic reaction was performed in $\mathrm{N}_{2}$ carrier gas flow at $300^{\circ} \mathrm{C}$, after $\mathrm{NH}_{3}$ gas had been flowed at a rate of $30 \mathrm{~cm}^{3} \mathrm{~min}^{-1}$ and $300^{\circ} \mathrm{C}$ for $0.5 \mathrm{~h}$ followed by preheating at $300{ }^{\circ} \mathrm{C}$ for $1 \mathrm{~h}$.

\section{Conclusions}

The vapor-phase catalytic dehydration of 1,4-BDO to form unsaturated alcohols such as 3B1ol was investigated over 16 REZrO samples together with the dehydration of 1,3- and 2,3-BDO. REZrO with heavy rare earth metals, especially oxygen-defected fluorite $\mathrm{Y}_{2} \mathrm{Zr}_{2} \mathrm{O}_{7}$, showed high conversion of 1,4-BDO to 3B1ol and also high conversion of 1,3-BDO to form 3B2ol and 2B1ol, while 2,3-BDO was less reactive than the other BDOs over REZrO catalysts. The high crystallinity of oxygen-defected fluorite $\mathrm{Y}_{2} \mathrm{Zr}_{2} \mathrm{O}_{7}$ with high surface area was synthesized in the HT treatment of do-precipitate hydroxide in ammonia media. $\mathrm{Y}_{2} \mathrm{Zr}_{2} \mathrm{O}_{7}$ has advantage in the industrial application because of the highest conversion based on weight. The calcination and crystallinity of $\mathrm{Y}_{2} \mathrm{Zr}_{2} \mathrm{O}_{7}$ affected the catalytic activity of the dehydration of BDOs: a calcination temperature of $900{ }^{\circ} \mathrm{C}$ or higher was efficient for selective formation of UOLs. In the dehydration of 1,4-BDO, 3B1ol, and THF were the primary products over $\mathrm{Y}_{2} \mathrm{Zr}_{2} \mathrm{O}_{7}$ catalyst, while 3B1ol was further reacted to form 2B1ol and BD. To the best of our knowledge, $\mathrm{Y}_{2} \mathrm{Zr}_{2} \mathrm{O}_{7}$ showed the highest 3B1ol productivity of $27.0 \mathrm{~mol} \mathrm{~h}^{-1} \mathrm{~kg}^{-1}$ in the dehydration of 1,4-BDO at $325^{\circ} \mathrm{C}$. In the poisoning experiment, both $\mathrm{CO}_{2}$ and $\mathrm{NH}_{3}$ behaved as poisons during the dehydration of 1,4-BDO. This suggests that the reaction proceeds via acid-base concerted mechanism.

Supplementary Materials: The following are available online at http://www.mdpi.com/2073-4344/10/12/1392/s1, Figure S1, $\mathrm{N}_{2}$ adsorption-desorption isotherm of $\mathrm{YZrO}$; Figure S2, XRD pattern of $\mathrm{YZrO}$ calcined at $900{ }^{\circ} \mathrm{C}$ together with PDF data; Figure S3, Changes in catalytic activity of $\mathrm{YZrO}$ calcined at $900{ }^{\circ} \mathrm{C}$ with TOS with and without $\mathrm{NH}_{3}$ pre-adsorption prior to the reaction; Figure S4, original TCD signal profiles in the TPD measurement of $\mathrm{NH}_{3}$ and $\mathrm{CO}_{2}$ desorbed from $\mathrm{YZrO}$ calcined at 600 and $900{ }^{\circ} \mathrm{C}$; Table S1, Dehydration of 1,4-BDO over YZrO calcined at different temperatures; Table S2, Dehydration of 1,4-BDO over YZrO calcined at $900{ }^{\circ} \mathrm{C}$ with different space time; Table S3, Dehydration of 1,3-BDO over sixteen REZrO catalysts; Table S4, Dehydration of 1,4-BDO over $\mathrm{YZrO}$ calcined at $900^{\circ} \mathrm{C}$ in different cold trap.

Author Contributions: A.M., Y.M., K.N., F.S. and S.S. summarized the data and prepared the original draft; A.M. and Y.M. prepared samples; A.M., Y.M. and K.N. performed catalytic tests in the dehydration of butanediols; A.M., Y.M., F.S. and R.T. characterized the samples; Y.Y. supervised the analytical work; S.S. designed the project, acquired funding, and edited the manuscript. All authors have read and agreed to the published version of the manuscript.

Funding: This work was funded by JSPS KAKENHI KIBAN B, grant number JP18H01784.

Conflicts of Interest: The authors declare no conflict of interest.

\section{References}

1. Ji, X.J.; Huang, H.; Ouyang, P.K. Microbial 2,3-butanediol production: A state-of-the-art review. Biotechnol. Adv. 2011, 29, 351-364. [CrossRef] [PubMed]

2. Zeng, A.P.; Sabra, W. Microbial production of diols as platform chemicals: Recent progresses. Curr. Opin. Biotechnol. 2011, 22, 749-757. [CrossRef] [PubMed]

3. Jang, Y.S.; Kim, B.; Shin, J.H.; Choi, Y.J.; Choi, S.; Song, C.W.; Lee, J.; Park, H.G.; Lee, S.Y. Bio-based production of C2-C6 platform chemicals. Biotechnol. Bioeng. 2012, 109, 2437-2459. [CrossRef] [PubMed]

4. Jiang, T.; Liu, W.; Zou, H.; Cheng, T.; Tian, N.; Xian, M. Microbial production of short chain diols. Microb. Cell Fact. 2014, 13, 165. [CrossRef]

5. Sabra, W.; Groeger, C.; Zeng, A.P. Microbial cell factories for diol production. Adv. Biochem. Eng. Biotechnol. 2016, 155, 165-197. 
6. Yang, T.; Rao, Z.; Zhang, X.; Xu, M.; Xu, Z.; Yang, S.T. Metabolic engineering strategies for acetoin and 2,3-butanediol production: Advances and prospects. Critic. Rev. Biotechnol. 2017, 37, 990-1005. [CrossRef]

7. Biz, A.; Proulx, S.; Xu, Z.; Siddartha, K.; Indrayanti, A.M.; Mahadevan, R. Systems biology based metabolic engineering for non-natural chemicals. Biotechnol. Adv. 2019, 37, 107379. [CrossRef]

8. Yim, H.; Haselbeck, R.; Niu, W.; Pujol-Baxley, C.; Burgard, A.; Boldt, J.; Khandurina, J.; Trawick, J.D.; Osterhout, R.E.; Stephen, R.; et al. Metabolic engineering of Escherichia coli for direct production of 1,4-butanediol. Nat. Chem. Biol. 2011, 7, 445-452. [CrossRef]

9. Liu, H.; Lu, T. Autonomous production of 1,4-butanediol via a de novo biosynthesis pathway in engineered Escherichia coli. Metab. Eng. 2015, 29, 135-141. [CrossRef]

10. Wang, J.; Jain, R.; Shen, X.; Sun, X.; Cheng, M.; Liao, J.C.; Yuan, Q.; Yan, Y. Rational engineering of diol dehydratase enables 1,4-butanediol biosynthesis from xylose. Metab. Eng. 2017, 40, 148-156. [CrossRef]

11. Tai, C.; Shen, Y.; Guo, Y.; Tao, F. Biosynthesis of 1,4-butanediol from erythritol using whole-cell catalysis. Biocatal. Biotrans. 2019, 37, 92-96.

12. Ly, B.K.; Minh, D.P.; Pinel, C.; Besson, M.; Tapin, B.; Epron, F.; Especel, C. Effect of addition mode of Re in bimetallic $\mathrm{Pd}-\mathrm{Re} / \mathrm{TiO}_{2}$ catalysts upon the selective aqueous-phase hydrogenation of succinic acid to 1,4-butanediol. Top. Catal. 2012, 55, 466-473. [CrossRef]

13. Kataoka, N.; Vangnai, A.S.; Tajima, T.; Nakashimada, Y.; Kato, J. Improvement of (R)-1,3-butanediol production by engineered Escherichia coli. J. Biosci. Bioeng. 2013, 115, 475-480. [CrossRef] [PubMed]

14. Nemr, K.; Müller, J.E.N.; Joo, J.C.; Gawand, P.; Choudhary, R.; Mendonca, B.; Lu, S.; Yu, X.; Yakunin, A.F.; Mahadevan, R. Engineering a short, aldolase-based pathway for (R)-1,3-butanediol production in Escherichia coli. Metab. Eng. 2018, 48, 13-24. [CrossRef]

15. Matsuyama, A.; Yamamoto, H.; Kawada, N.; Kobayashi, Y. Industrial production of (R)-1,3-butanediol by new biocatalysts. J. Mol. Catal. B Enzym. 2001, 11, 513-521. [CrossRef]

16. Itoh, N.; Nakamura, M.; Inoue, K.; Makino, Y. Continuous production of chiral 1,3-butanediol using immobilized biocatalysts in a packed bed reactor: Promising biocatalysis method with an asymmetric hydrogen-transfer bioreduction. Appl. Microbiol. Biotechnol. 2007, 75, 1249-1256. [CrossRef]

17. Sato, S.; Sato, F.; Gotoh, H.; Yamada, Y. Selective dehydration of alkanediols into unsaturated alcohols over rare earth oxide catalysts. ACS Catal. 2013, 3, 721-734. [CrossRef]

18. Duan, H.; Yamada, Y.; Sato, S. Future prospect of the production of 1,3-butadiene from butanediols. Chem. Lett. 2016, 45, 1036-1047. [CrossRef]

19. Zeng, F.; Hohn, K. Catalytic conversion of biomass-derived compounds to C4 chemicals. Catalysis 2019, 31, $1-36$.

20. Sun, D.; Li, Y.; Yang, C.; Su, Y.; Yamada, Y.; Sato, S. Production of 1,3-butadiene from biomass-derived C4 alcohols. Fuel Proc. Technol. 2020, 197, 106193. [CrossRef]

21. Kim, W.; Shin, W.; Lee, K.J.; Song, H.; Kim, H.S.; Seung, D.; Filimonov, I.N. 2,3-Butanediol dehydration catalyzed by silica-supported sodiumphosphates. Appl. Catal. A Gen. 2016, 511, 156-167. [CrossRef]

22. Tsukamoto, D.; Sakami, S.; Ito, M.; Yamada, K.; Yonehara, T. Production of bio-based 1,3-butadiene by highly selective dehydration of 2,3-butanediol over $\mathrm{SiO}_{2}$-supported cesium dihydrogen phosphate catalyst. Chem. Lett. 2016, 45, 831-833. [CrossRef]

23. Jing, F.; Katryniok, B.; Araque, M.; Wojcieszak, R.; Capron, M.; Paul, S.; Daturi, M.; Clacens, J.M.; De Campo, F.; Liebens, A.; et al. Direct dehydration of 1,3-butanediol into butadiene over aluminosilicate catalysts. Catal. Sci. Technol. 2016, 6, 5830-5840. [CrossRef]

24. Jing, F.; Katryniok, B.; Paul, S.; Fang, L.; Liebens, A.; Shen, M.; Hu, B.; Dumeignil, F.; Pera-Titus, M. Al-doped SBA-15 catalysts for low-temperature dehydration of 1,3-butanediol into butadiene. ChemCatChem 2017, 9 , 258-262. [CrossRef]

25. Fang, L.; Jing, F.; Lu, J.; Hu, B.; Pera-Titus, M. Nano-flowered Ce@MOR hybrids with modulated acid properties for the vapor-phase dehydration of 1,3-butanediol into butadiene. Green Chem. 2017, 19, 4610-4621. [CrossRef]

26. Lee, J.H.; Hong, S.B. Dehydration of 1,3-butanediol to butadiene over medium-pore zeolites: Another example of reaction intermediate shape selectivity. Appl. Catal. B Environ. 2021, 280, 119446. [CrossRef]

27. Yamamoto, N.; Sato, S.; Takahashi, R.; Inui, K. Synthesis of homoallyl alcohol from 1,4-butanediol over $\mathrm{ZrO}_{2}$ catalyst. Catal. Commun. 2005, 6, 480-484. [CrossRef] 
28. Yamamoto, N.; Sato, F.; Takahashi, R.; Inui, K. Synthesis of 3-buten-1-ol from 1,4-butanediol over $\mathrm{ZrO}_{2}$ catalyst. J. Mol. Catal. A Chem. 2006, 243, 52-59. [CrossRef]

29. Sato, F.; Yamada, Y.; Sato, S. Preparation of $\mathrm{Er}_{2} \mathrm{O}_{3}$ nanorod catalyst without using organic additive and its application to catalytic dehydration of 1,4-butanediol. Chem. Lett. 2012, 41, 593-594. [CrossRef]

30. Sato, F.; Sato, S.; Yamada, Y.; Nakamura, M.; Shiga, A. Acid-base concerted mechanism in the dehydration of 1,4-butanediol over bixbyite rare earth oxide catalysts. Catal. Today 2014, 226, 124-133. [CrossRef]

31. Zhang, Q.; Zhang, Y.; Li, H.; Gao, C.; Zhao, Y. Heterogeneous $\mathrm{CaO}-\mathrm{ZrO}_{2}$ acid-base bifunctional catalysts for vapor-phase selective dehydration of 1,4-butanediol to 3-buten-1-ol. Appl. Catal. A Gen. 2013, 466, 233-239. [CrossRef]

32. Inoue, H.; Sato, S.; Takahashi, R.; Izawa, Y.; Ohno, H.; Takahashi, K. Dehydration of 1,4-butanediol over supported rare earth oxide catalysts. Appl. Catal. A Gen. 2009, 352, 66-73. [CrossRef]

33. Duan, H.; Hirota, T.; Yamada, Y.; Sato, S. Vapor-phase catalytic dehydration of 1,4-butanediol to 3-buten-1-ol over modified $\mathrm{ZrO}_{2}$ catalysts. Appl. Catal. A Gen. 2017, 535, 9-16. [CrossRef]

34. Ohtsuka, S.; Nemoto, T.; Yotsumoto, R.; Yamada, Y.; Sato, F.; Takahashi, R.; Sato, S. Vapor-phase catalytic dehydration of butanediols to unsaturated alcohols over yttria-stabilized zirconia catalysts. Appl. Catal. A Gen. 2019, 575, 48-57. [CrossRef]

35. Nemoto, T.; Yamada, Y.; Sato, F.; Takahashi, R.; Sato, S. Catalytic dehydration of 1,3-butanediol over oxygen-defected fluorite $\mathrm{Yb}_{2} \mathrm{Zr}_{2} \mathrm{O}_{7}$. Mol. Catal. 2019, 473, 110399. [CrossRef]

36. Fang, X.; Xia, L.; Peng, L.; Luo, Y.; Xu, J.; Xu, L.; Xu, X.; Liu, W.; Zheng, R.; Wang, X. Ln $_{2} Z_{2} \mathrm{O}_{7}$ compounds ( $\mathrm{Ln}=\mathrm{La}, \mathrm{Pr}, \mathrm{Sm}, \mathrm{Y})$ with varied rare earth A sites for low temperature oxidative coupling of methane. Chin. Chem. Lett. 2019, 30, 1141-1146. [CrossRef]

37. Shanon, R.D. Revised effective ionic radii and systematic studies of interatomic distances in halides and chalcogenides. Acta Cryst. 1976, A32, 751-767. [CrossRef]

38. Duan, H.; Sun, D.; Yamada, Y.; Sato, S. Dehydration of 2,3-butanediol into 3-buten-2-ol catalyzed by $\mathrm{ZrO}_{2}$. Catal. Commun. 2014, 48, 1-4. [CrossRef]

39. Duan, H.; Yamada, Y.; Sato, S. Vapor-phase catalytic dehydration of 2,3-butanediol into 3-buten-2-ol over $\mathrm{Sc}_{2} \mathrm{O}_{3}$. Chem. Lett. 2014, 43, 1773-1775. [CrossRef]

40. Sun, D.; Arai, S.; Duan, H.; Yamada, Y.; Sato, S. Vapor-phase dehydration of C4 unsaturated alcohols to 1,3-butadiene. Appl. Catal. A Gen. 2017, 531, 21-28. [CrossRef]

41. Wang, Y.; Sun, D.; Yamada, Y.; Sato, S. Selective production of 1,3-butadiene in the dehydration of 1,4-butanediol over rare earth oxides. Appl. Catal. A Gen. 2018, 562, 11-18. [CrossRef]

42. Chen, D.; Xu, R. Hydrothermal synthesis and characterization of $\mathrm{La}_{2} \mathrm{M}_{2} \mathrm{O}_{7}(\mathrm{M}=\mathrm{Ti}, \mathrm{Zr})$ powders. Mater. Res. Bull. 1998, 33, 409-417. [CrossRef]

43. Liu, Z.-G.; Ouyang, J.-H.; Zhou, Y.; Li, J.; Xia, X.-L. Densification, structure, and thermophysical properties of ytterbium-gadolinium zirconate ceramics. Int. J. Appl. Ceram. Technol. 2009, 6, 485-491. [CrossRef]

44. Walker, J.D.S.; Hayes, J.R.; Gaultois, M.W.; Aluri, E.R.; Grosvenor, A.P. A case for oxygen deficiency in $\mathrm{Gd}_{2} \mathrm{Ti}_{2-x} \mathrm{Zr}_{x} \mathrm{O}_{7}$ pyrochlore-type oxides. J. Alloys Compd. 2013, 565, 44-49. [CrossRef]

45. Gotoh, H.; Yamada, Y.; Sato, S. Dehydration of 1,3-butanediol over rare earth oxides. Appl. Catal. A Gen. 2010, 377, 92-98. [CrossRef]

46. Sato, S.; Takahashi, R.; Kobune, M.; Inoue, H.; Izawa, Y.; Ohno, H.; Takahashi, K. Dehydration of 1,4-butanediol over rare earth oxides. Appl. Catal. A Gen. 2009, 356, 64-71. [CrossRef]

47. Kobune, M.; Sato, S.; Takahashi, R. Surface-structure sensitivity of $\mathrm{CeO}_{2}$ for several catalytic reactions. J. Mol. Catal. A Chem. 2008, 279, 10-19. [CrossRef]

48. Sharma, S.; Hilaire, S.; Vohs, J.M.; Gorte, R.J.; Jen, H.-W. Evidence for oxidation of ceria by $\mathrm{CO}_{2}$. J. Catal. 2000, 190, 199-204. [CrossRef]

49. Moulijn, J.A.; Tarfaoui, A.; Kapteijn, F. General aspects of catalyst testing. Catal. Today 1991, 11, 1-12. [CrossRef]

50. Sato, S.; Takahashi, R.; Sodesawa, T.; Yamamoto, N. Dehydration of 1,4-butanediol into 3-buten-1-ol catalyzed by ceria. Catal. Commun. 2004, 5, 397-400. [CrossRef]

51. Ichikawa, N.; Sato, S.; Takahashi, R.; Sodesawa, T. Catalytic reaction of 1,3-butanediol over solid acids. J. Mol. Catal. A Chem. 2006, 256, 106-112. [CrossRef]

52. Duan, H.; Yamada, Y.; Sato, S. Selective dehydration of 2,3-butanediol to 3-buten-2-ol over $\mathrm{ZrO}_{2}$ modified with CaO. Appl. Catal. A Gen. 2014, 487, 226-233. [CrossRef] 
53. Izumi, F.; Momma, K. Three-dimensional visualization in powder diffraction. Solid State Phenom. 2007, 130, 15-20. [CrossRef]

54. Lide, D.R. CRC Handbook of Chemistry and Physics, 82th ed.; CRC Press: London, UK, 2001; pp. 4-95-4-96.

55. Takahashi, R.; Yamada, I.; Iwata, A.; Kurahashi, N.; Yoshida, S.; Sato, S. Synthesis of 3-buten-1-ol from 1,4-butanediol over indium oxide. Appl. Catal. A Gen. 2010, 383, 134-140. [CrossRef]

56. Wattanasiriwech, D.; Wattanasiriwech, S. Effects of fuel contents and surface modification on the sol-gel combustion $\mathrm{Ce}_{0.9} \mathrm{Gd}_{0.1} \mathrm{O}_{1.95}$ nanopowder. Energy Procedia 2013, 34, 524-533. [CrossRef]

57. Yavetskiy, R.P.; Kosyanov, D.Y.; Baumer, V.N.; Doroshenko, A.G.; Fedorov, A.I.; Matveevskaya, N.A.; Tolmachev, A.V.; Vovk, O.M. Low-agglomerated yttria nanopowders via decomposition of sulfate-doped precursor with transient morphology. J. Rare Earth 2014, 32, 320-325. [CrossRef]

Publisher's Note: MDPI stays neutral with regard to jurisdictional claims in published maps and institutional affiliations.

(C) 2020 by the authors. Licensee MDPI, Basel, Switzerland. This article is an open access article distributed under the terms and conditions of the Creative Commons Attribution (CC BY) license (http://creativecommons.org/licenses/by/4.0/). 